\title{
Black carbon from ships: a review of the effects of ship speed, fuel quality and exhaust gas scrubbing
}

\author{
D. A. Lack $^{1,2}$ and J. J. Corbett ${ }^{3}$ \\ ${ }^{1}$ Chemical Sciences Division, Earth System Research Laboratory, NOAA, Boulder, Colorado, USA \\ ${ }^{2}$ Cooperative Institute for Research in Environmental Sciences, University of Colorado, Boulder, Colorado, USA \\ ${ }^{3}$ College of Marine and Earth Studies, University of Delaware, Newark, Delaware, USA
}

Correspondence to: D. A. Lack (daniel.lack@noaa.gov)

Received: 28 December 2011 - Published in Atmos. Chem. Phys. Discuss.: 31 January 2012

Revised: 10 April 2012 - Accepted: 13 April 2012 - Published: 4 May 2012

\begin{abstract}
The International Maritime Organization (IMO) has moved to address the health and climate impact of the emissions from the combustion of low-quality residual fuels within the commercial shipping industry. Fuel sulfur content $\left(F_{S}\right)$ limits and an efficiency design index for future ships are examples of such IMO actions. The impacts of black carbon (BC) emissions from shipping are now under review by the IMO, with a particular focus on the potential impacts of future Arctic shipping.

Recognizing that associating impacts with $\mathrm{BC}$ emissions requires both ambient and onboard observations, we provide recommendations for the measurement of BC. We also evaluate current insights regarding the effect of ship speed (engine load), fuel quality and exhaust gas scrubbing on BC emissions from ships. Observations demonstrate that $\mathrm{BC}$ emission factors $\left(\mathrm{EF}_{\mathrm{BC}}\right)$ increases 3 to 6 times at very low engine loads ( $<25 \%$ compared to $\mathrm{EF}_{\mathrm{BC}}$ at $85-100 \%$ load); absolute $\mathrm{BC}$ emissions (per nautical mile of travel) also increase up to $100 \%$ depending on engine load, even with reduced load fuel savings. If fleets were required to operate at lower maximum engine loads, presumably associated with reduced speeds, then engines could be re-tuned, which would reduce $\mathrm{BC}$ emissions.

Ships operating in the Arctic are likely running at highly variable engine loads $(25-100 \%)$ depending on ice conditions and ice breaking requirements. The ships operating at low load may be emitting up to $50 \%$ more BC than they would at their rated load. Such variable load conditions make it difficult to assess the likely emissions rate of BC.

Current fuel sulfur regulations have the effect of reducing $\mathrm{EF}_{\mathrm{BC}}$ by an average of $30 \%$ and potentially up to $80 \%$
\end{abstract}

regardless of engine load; a removal rate similar to that of scrubbers.

Uncertainties among current observations demonstrate there is a need for more information on a) the impact of fuel quality on $\mathrm{EF}_{\mathrm{BC}}$ using robust measurement methods and $\mathrm{b}$ ) the efficacy of scrubbers for the removal of particulate matter by size and composition.

\section{Introduction}

The commercial shipping industry, through the United Nations International Maritime Organization (IMO), is subject to regulation on the quality of fuel that can be consumed within specially designated emission control areas (ECAs), in particularly sensitive regions like the Antarctic, and globally (IMO, 2008, 2009). These fuel quality requirements are motivated both by safety concerns about engine operation and vessel navigation (ISO, 1987), and to achieve human health and environmental protections from engine exhaust products. The IMO has also specified an efficiency design index that will reduce ship fuel consumption for energy savings and greenhouse gas emission reductions (IMO, 2011c) for an industry that emits $3.3 \%$ of global $\mathrm{CO}_{2}$ emissions (Buhaug et al., 2009). Current IMO environmental regulations are directed at limiting the emissions of sulfur dioxide $\left(\mathrm{SO}_{2}\right)$ which forms acid rain (harmful to ecosystems) and air quality-degrading primary and secondary particles. Ships contribute between 5 and $8 \%$ of global anthropogenic $\mathrm{SO}_{2}$ emissions (Eyring et al., 2005). 
Shipping emissions of concern for health include secondary ozone (formed from $\mathrm{NO}_{\mathrm{x}}$ emissions), secondary particulate sulfate (formed from gaseous sulfur dioxide emissions) and directly emitted particulate sulfate, organic matter and black carbon (BC). Evidence is emerging that $\mathrm{BC}$ has a distinct health effect compared to other particulates despite being only a small fraction of PM mass emitted by many sources (Smith et al., 2009). Corbett et al. (2007) and Winebrake et al. (2009) identified the magnitude of current health impacts from shipping and those reductions in health impacts that would be brought about by the IMO regulations.

Shipping emissions also alter the radiative balance of the atmosphere via warming by $\mathrm{CO}_{2}$, ozone and $\mathrm{BC}$ emissions, and cooling by particulate sulfate formation and subsequent formation and alteration of clouds (Eyring et al., 2010; Lauer et al., 2009). Cooling can also result from ship $\mathrm{NO}_{\mathrm{x}}$ emissions reducing methane lifetime (Myhre et al., 2011). The cooling effect of particulate sulfate and the warming of $\mathrm{CO}_{2}$ dominate the radiative impacts of shipping, however $\mathrm{BC}$ can have significant localized warming both in the atmosphere and on snow and ice surfaces (Flanner et al., 2007; Hansen and Nazarenko, 2004; Ramanathan and Carmichael, 2008). Of particular concern for climate is the likelihood that retreating sea ice in the Arctic will allow for a significant increase in shipping activity and related emissions (IMO, 2010a). Shipping contributes about $2 \%$ to global BC emissions (Lack et al., 2008b), and currently very little in the Arctic (Corbett et al., 2010a). The vast majority of current Arctic BC is sourced from outside of the Arctic region (Quinn et al., 2011), and future ship traffic in the Arctic will be one of the few direct emissions of BC into the Arctic (Quinn et al., 2011). In addition, these added direct emissions will likely add to the climate impacts in that region (Corbett et al., 2010a; IMO, 2010a).

There are a number of alternatives for reducing emissions from shipping, some of which have already been assessed for their efficacy and cost effectiveness (e.g. speed reductions, fuel quality, engine slide valves, water-in-fuel emulsions, fuel emulsions, particulate filters, exhaust scrubbers) (Corbett et al., 2009; Corbett et al., 2010b). There are three pathways that hold particular promise for emissions reductions; the effect of ship speed reductions (or 'slow steaming'); fuel quality improvements; and exhaust scrubbers. These potential emissions mitigation options have not been rigorously assessed for their impact on $\mathrm{BC}$ emissions.

The recent downturn in the global economy led to a globally averaged reduction in ship speed of $15 \%$ (PWC, 2011), influenced by the reduced demand for voyages and financial savings through reductions in fuel consumption. Maintaining some form of ship speed reductions as industry practice or regulation has been discussed within industry and regulatory circles as an emissions reduction strategy. In addition, some coastal regions have mandatory or voluntary ship speed reduction programs, mostly motivated by minimizing ship whale strikes and improving air quality (CARB, 2009b;
NOAA, 2008; Port-of-San-Diego, 2009). For ships operating in optimal cruising conditions (open and calm waters), decreases in ship speed lead to decreases in absolute fuel consumption (as a cubic function) due to the reduced fluid resistance on the ship hull (Harvald, 1977), and so there can be significant $\mathrm{CO}_{2}$ and other emissions reductions for a small reduction in speed. However, as engines are usually tuned for maximum speed (c.f. load), operation at lower loads creates a less efficient combustion process that could lead to increases in emissions such as $\mathrm{CO}$ and BC.

Regulations on the quality of fuel used by ships are already in force in specific regions (IMO, 2008, 2009), where fuel sulfur content $\left(\mathrm{F}_{\mathrm{S}}\right)$, one aspect of fuel quality, is reduced so that emission of $\mathrm{SO}_{2}$ and primary and secondary particulate sulfate are also reduced. Significant improvements to air quality are expected from such regulation (IMO, 2009; Winebrake et al., 2009). However sparse data exist on how $\mathrm{BC}$ emissions from ship engines are affected by $\mathrm{F}_{\mathrm{S}}$ or other aspects of fuel quality. Fuel quality is a general term describing the relative level of impurities, as well as the combustion ability of the hydrocarbons within the fuel. Residual fuels, the fraction of crude oil remaining after the refining process, can contain high levels of sulfur, heavy metals (e.g. vanadium, nickel), ash (non-combustible inorganic material) and high molecular weight aromatic hydrocarbons. Each of these impurities (except perhaps for heavy metals) is known to create slower and delayed combustion, potentially leading to BC formation (American-Bureau-of-Shipping, 2001). It is therefore somewhat expected that better combustion and lower emissions per unit of fuel consumed result from combustion of more refined fuels, as compared to residual fuels. It is also known that heavy metals create localized hot-spots within the flame and catalyze combustion of BC (e.g. Maricq, 2007; Ristimaki et al., 2010).

An alternative to complying with low $\mathrm{F}_{\mathrm{S}}$ regulations is to employ exhaust gas scrubbers while still burning high sulfur (and the least expensive) fuel. Scrubbers can reduce gas and particle phase emissions from the exhaust stream before release to the atmosphere. Commercial organizations are developing scrubbers that are reported to provide $\mathrm{SO}_{2}$ emissions reductions equivalent to the use of low $\mathrm{F}_{\mathrm{S}}$ fuel required by regulation. Very little data exists on the efficacy of these scrubbers for $\mathrm{BC}$ emissions.

Here we review the science available on $\mathrm{BC}$ emissions from marine diesel engines. Section 2 of this paper considers several functional definitions for BC emissions variously provided in scientific literature. Section 2 also considers how these definitions emerge from (and/or align with) measurement methods to quantify $\mathrm{BC}$ emissions from international shipping (Sects. 2.1 through 2.6). The paper then investigates and compares three potential control measures to reduce $\mathrm{BC}$ emission[s] from international shipping, including (i) speed reduction (Sect. 3); (ii) improved fuel quality (Sect. 4); and exhaust treatment using scrubber technology (Sect. 5). The topics of this review were raised in the 62 nd session of the 
IMO Marine Environment Protection Committee (MEPC) and investigation was then tasked to the Bulk Liquids and Gases (BLG) subcommittee of the MEPC (IMO, 2011a). We limit this review to the data available for marine diesel engines, and data available in peer-reviewed literature, industry reports and presentations that are in the public domain, or industry data where permission has been granted to publish the data.

\section{Definition and measurement of black carbon}

We can define black carbon as a set of species of strongly light absorbing carbon particles emitted by combustion of organic compounds. Various terms used to describe this species are defined by the measurement techniques used. Andreae and Gelencser (2006) provide a comprehensive review of this topic. Briefly, elemental carbon (EC) is "the fraction of carbon that is oxidized in combustion analysis above a certain temperature threshold, and only in the presence of an oxygen-containing atmosphere" (Andreae and Gelencser, 2006). The technique to make this measurement is referred to as thermal-optical-analysis (TOA). Black carbon (BC) is the common term used for the mass of strongly light absorbing carbon derived from the absorption of a specific wavelength of light by the particles and where a wavelength specific mass-to-absorption coefficient (MAC) is used to convert from absorption to mass. The MAC for particles containing mostly fractal carbon freshly emitted from efficient combustion of fossil fuels is reasonably well defined $\left(7.5 \mathrm{~m}^{2} \mathrm{~g}^{-1}\right)$ for $550 \mathrm{~nm}$ radiation (Bond and Bergstrom, 2006; Cross et al., 2010). Refractory BC (rBC) is the terminology applied to the mass of material that incandesces (emits visible light) when heated with a laser (Schwarz et al., 2006).

There are multiple techniques and methods for measuring $\mathrm{EC}, \mathrm{BC}$ and $\mathrm{rBC}$. Each technique has potential advantages and drawbacks. TOA analysis (measuring $\mathrm{EC}_{\mathrm{TOA}}$ ) exhibit substantial potential biases and requires data corrections due to interference of organic particulates and selection of thermal profiles (Boparai et al., 2008). Filter based light absorption requires significant calibration and corrections and may also suffer from organic particulate and particle size biases (Arnott et al., 2005; Bond et al., 1999; Kondo et al., 2009; Lack et al., 2008a; Nakayama et al., 2010). A common technique for measuring the opacity created by engine exhaust smoke, the filter smoke number (FSN), is a filterbased absorption method that requires substantial empirical corrections to derive BC mass (Northrop et al., 2011). Uncertainties on mass derived from FSN measurements are therefore dependent on the fit to empirical data. Photo-acoustic absorption spectroscopy (PAS) is a more accurate, precise and sensitive measure of absorption compared to the filterbased techniques (Arnott et al., 2006; Lack et al., 2006; Lack et al., 2008b). Laser induced incandescence (LII) is probably the most fundamental measurement of the strongly light absorbing carbon material, although this technique requires very careful calibration and operation (Cross et al., 2010; Moteki and Kondo, 2010). Most of these techniques have been applied to the measurement of $\mathrm{EC}$ or $\mathrm{BC}$ from diesel engine emissions (Burtscher, 2005). However, most of the techniques mentioned here show variable levels of agreement to one another when measuring ship engine exhaust despite the fact that they can show excellent agreement with each other under controlled laboratory conditions with controlled samples (Cross et al., 2010; Kondo et al., 2011; Sheridan et al., 2005). Moosmuller et al. (2009) provides additional details in their comprehensive review of the measurement techniques for particle light absorption. A single measurement technique for the target species would be the ideal to ensure consistent measurement and analysis. However, the varying degrees of expense, ease of use, and data accuracy of the instrumentation explain why different organizations may favor a specific technique for measuring ship, or engine emissions. Using consistent measurement methods (e.g. calibrations, corrections, temperature profiles, dilution etc.) is also essential. For example, one of the most important parameters in measuring combustion engine exhaust emissions is sample dilution. Burtscher (2005) highlight the inaccuracies in measurement of emissions from diesel engines when different exhaust dilution ratios are used. Ristimaki et al. (2010) found that accuracy of particulate mass measurement improved as dilution increased; dilution factors beyond the ISO-8178-1 standard were required for reproducible measurement. Note that the ISO 8178 standard specifies the test load cycles for emissions measurements from non-road vehicles. In addition it specifies a minimum dilution of the emitted exhaust prior to sampling. In this review we focus only on measurements made on the emissions of marine diesel engines. Sects. 2.1 through 2.5 compare $\mathrm{EC}, \mathrm{BC}$ and $\mathrm{rBC}$ measurements for emissions from marine diesel engines. We use the following terminology: photo-acoustic derived $\mathrm{BC}$ is $\mathrm{BC}_{\mathrm{PAS}}$, filterbased absorption-derived $\mathrm{BC}$ is $\mathrm{BC}_{\text {Filter, }}$ LII $\mathrm{BC}$ is $\mathrm{rBC}$, filter smoke number derived $\mathrm{BC}$ is $\mathrm{BC}_{\mathrm{FSN}}$ and thermal optical analysis $\mathrm{EC}$ is $\mathrm{EC}_{\mathrm{TOA}}$.

\subsection{PAS BC - filter BC}

Lack et al. (2008b) measured light absorption and converted this to $\mathrm{BC}$ mass emission factors (BC $\mathrm{BAS}$ ) from almost 100 ships. In a follow-up study Lack et al. (2009) compared these emission factors where both PAS and a filter-based absorption instrument (particle soot absorption photometer, PSAP) measured the same plume. Cappa et al. (2012) also measured

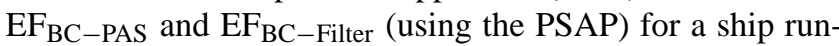
ning a medium speed diesel (MSD) engine. The conversion from absorption to mass used a literature MAC value that can be applied to absorption measurements at the wavelength of $532 \mathrm{~nm}\left(7.75 \mathrm{~m}^{2} \mathrm{~g}^{-1}\right)$. Figure 1a shows the comparison of these data and reveals excellent agreement between two independent techniques for measuring $\mathrm{BC}$ emissions, from 

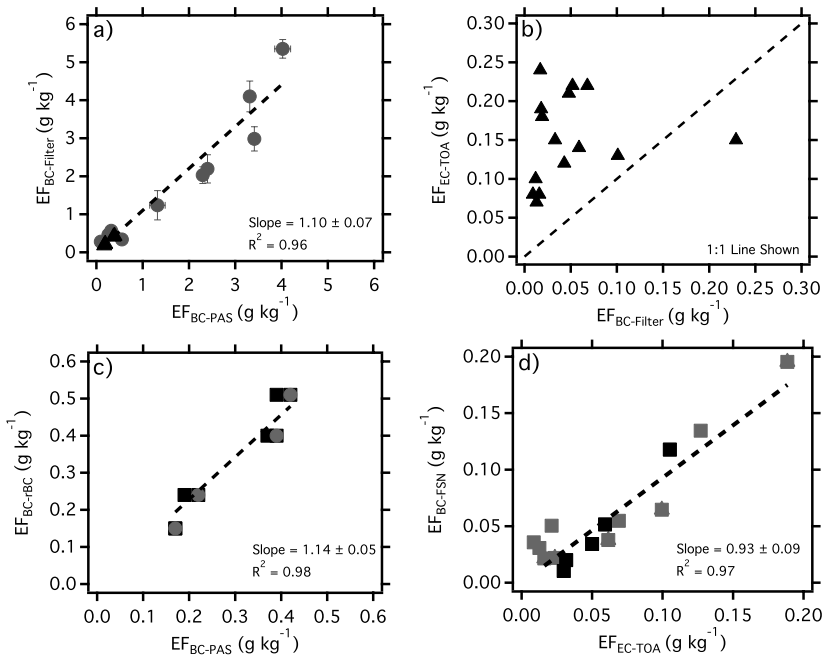

Fig. 1. Comparison of emission factors from marine diesel engines.

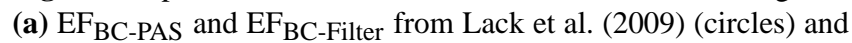

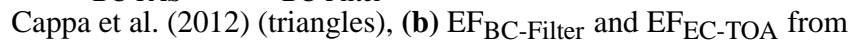
Petzold et al. (2011a), (c) EFBC-rBC and EFBC-PAS from Cappa et al. (2012) and (d) $\mathrm{EF}_{\mathrm{EC}-\mathrm{TOA}}$ and $\mathrm{EF}_{\mathrm{BC}-\mathrm{FSN}}$ from Ristimaki et al. (2010). Linear regression fit shown by dashed line in (a), (c) and (d). 1:1 line shown by dashed line in (b).

two independent studies. These data are for emissions from marine diesel engines under real world operating conditions where thermal equilibration and large dilution with the atmosphere has occurred, eliminating dilution issues discussed in Sect. 2.

\subsection{Filter BC - TOA EC}

Petzold et al. (2011a) measured both $\mathrm{EC}_{\mathrm{TOA}}$ and $\mathrm{BC}_{\mathrm{Filter}}$ for emissions using a variety of fuels used in a marine diesel engine. Those results (Fig. 1b) show a strong deviation from the expected correlation of 1. Measured $\mathrm{EC}_{\mathrm{TOA}}$ is over twice that of measured $\mathrm{BC}_{\mathrm{Filter}}$ (using a multi angle absorption photometer, MAAP), with some significant scatter. Measurements were performed using the ISO-8178 standard. In a study on gas turbine engines, Petzold et al. (2011b) showed that a similar discrepancy between $\mathrm{BC}_{\mathrm{Filter}}$ and $\mathrm{EC}_{\mathrm{TOA}}$ was anti correlated to the amount of particulate organic matter (POM) present, and suggested that pyrolysis of POM to $\mathrm{EC}_{\mathrm{TOA}}$ could occur. This interpretation was supported by the broader inter-comparison study of Schmid et al. (2001).

\subsection{PAS BC- LII rBC}

Cappa et al. (2012) were able to measure $\mathrm{BC}_{\mathrm{PAS}}$ and $\mathrm{rBC}$ emission factors for a ship running a MSD engine off the coast of California in 2010. A comparison of data from four plume intercepts using LII and two independent PAS measurements (Fig. 1c) show a slope of 1.14 and $R^{2}$ of 0.94 for the 8 measurements. This excellent correlation close to a slope of 1 indicates that the mass absorption coefficient used, $7.75 \mathrm{~m}^{2} \mathrm{~g}^{-1}$, is generally valid for this dataset, which is an important consideration for the translation of light absorption and mass measurements (IMO, 2011b).

\subsection{TOA EC - FSN BC}

Ristimaki et al. (2010) measured $\mathrm{EC}_{\mathrm{TOA}}$ and FSN for three types of fuels (two low quality and one high quality) at various load conditions. This study compared emissions between high and low fuel quality used in the same engine at varying loads. The FSN is a unitless number derived from filter based light absorption. The measurement technique has known biases (Northrop et al., 2011) that can, in principle, be corrected (Christian et al., 1993) and then translated into BC concentrations. We apply the Christian et al. (1993) correction to all the FSN data in this review to produce a $\mathrm{BC}_{\mathrm{FSN}}$ mass emission factor. The FSN requires a factor of 10 or more correction to derive $\mathrm{BC}$ mass concentrations $\left(\mathrm{g} \mathrm{m}^{-3}\right)$. Despite these corrections being somewhat uncertain, Fig. 1d generally shows good agreement between the FSN and TOA methods, although the scatter in the data appears to increase at low EF values. The ISO-8179 standard was altered in this study to reduce dilution biases.

\subsection{LII rBC - TOA EC}

There are no published studies where the same BC emissions from marine diesel engines have been measured using LII $(\mathrm{rBC})$ and TOA $\left(\mathrm{EC}_{\mathrm{TOA}}\right)$.

\subsection{Measurement methods summary}

This assessment of limited available data sets show that $\mathrm{BC}_{\mathrm{PAS}}, \mathrm{BC}_{\text {Filter }}$ and $\mathrm{rBC}$ are consistent measurement techniques for $\mathrm{BC}$ emissions from ships. There is a poor correlation for $\mathrm{EC}_{\mathrm{TOA}}$ and $\mathrm{BC}_{\mathrm{Filter}}$ for the one study where both were used for the measurement of $\mathrm{BC}$ from a marine engine. Under controlled laboratory conditions there is consistency between $\mathrm{BC}_{\mathrm{Filter}}, \mathrm{EC}_{\mathrm{TOA}}$ and $\mathrm{rBC}$, however there appears to be some inconsistency between $\mathrm{EC}_{\mathrm{TOA}}$ and $\mathrm{BC}_{\mathrm{Filter}}$ in field measurements of ship exhaust, very likely due to the POM content of the exhaust causing biases in the measurement (Petzold et al., 2011b; Schmid et al., 2001). $\mathrm{EC}_{\mathrm{TOA}}$ and $\mathrm{BC}_{\mathrm{FSN}}$ show good agreement in one study, suggesting that biases were not significant in that study. This suggests that the $\mathrm{EC}_{\mathrm{TOA}}$ method is not nearly as reliable a tool for measurement of BC. In addition, the TOA method does not have the requisite time resolution to do plume analysis. We therefore conclude that $\mathrm{BC}_{\mathrm{PAS}}, \mathrm{BC}_{\mathrm{Filter}}$ and $\mathrm{rBC}$ can be used for absolute emissions measurements, both in engine test bed studies and atmospheric sampling. Although $\mathrm{BC}_{\mathrm{FSN}}$ and $\mathrm{EC}_{\mathrm{TOA}}$ showed good agreement, obtaining $\mathrm{BC}$ mass from FSN requires substantial empirical corrections that expand the measurement uncertainties. Measurements of emissions after significant dilution beyond that recommended by 
the ISO 8178 standard for measuring engine exhaust emissions show the best comparison among instruments. Dilution is a significant factor in the measurement of diesel exhaust emissions, in particular the measured mass of particulate organic matter (POM) (Burtscher, 2005; Ristimaki et al., 2010). POM can impact the artifacts within the TOA method (Boparai et al., 2008). The use of the TOA method will be further discussed in Sect. 4. From this point forward, all data are presented in relative terms normalized to $85-100 \%$ load or as a ratio between 'before' and 'after' measurements (e.g. low to high fuel quality). We rely upon the equivalency between $\mathrm{BC}, \mathrm{rBC}$ and $\mathrm{EC}$ under this method of presentation. In general discussion we will refer to $\mathrm{EC}, \mathrm{BC}$ and $\mathrm{rBC}$ as simply BC.

\section{Effect of engine load}

We investigate how the load of a marine diesel engine affects $\mathrm{BC}$ emissions using original and metadata from published studies. Under ideal conditions, main engine load is correlated with vessel speed. How would mandatory or incentivebased ship speed limits affect BC emissions? What insights for potential future ship speed regulation can be found within the data currently available?

\subsection{Literature review}

Marine diesel engines can be tuned for maximum energy output at minimum fuel consumption during operation at the most common engine load conditions expected (American-Bureau-of-Shipping, 2001). Maximum efficiency results from the highest ratio between the maximum pressure at the top of the piston stroke $\left(P_{\mathrm{MAX}}\right)$ to the average pressure across the cylinder cycle $\left(P_{\mathrm{Avg}}\right)$; in the case of marine diesel engines the brake mean effective pressure $\left(P_{\mathrm{BMEP}}\right)$ is an often used version of $P_{\mathrm{Avg}}$ that considers engine torque (Wettstein and Brown, 2008). Under such tuning conditions these engines consume the least amount of fuel for each unit of work, and likewise produce the least amount of BC particles. When engines operate outside of the tuned engine load without retuning, fuel efficiency often decreases and emissions (including BC) increase due to variations in conditions away from ideal combustion. Engines can be re-tuned for different loads in a process where the $P_{\text {Max }} / P_{\mathrm{BMEP}}$ is maximized (Wettstein and Brown, 2008); some advanced engines with electronically controlled fuel meters may be able to modify combustion settings, per cylinder, essentially tuning during operational changes to better approximate bestperformance conditions. De-rating would likely be carried out if the engine were to operate at that new load on a somewhat permanent basis. Fuel efficiency can be improved by a few percent when de-rating is performed for loads lower than the maximum design load (Wettstein and Brown, 2008)

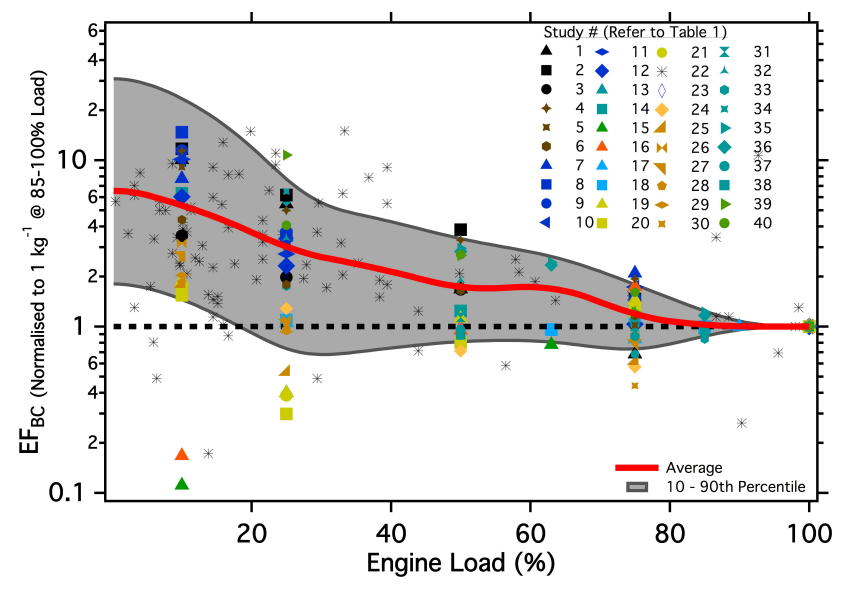

Fig. 2. The relationship between $\mathrm{EF}_{\mathrm{BC}}$ and ship engine load. Average $=$ red, 10th and 90th percentile $=$ grey.

(note: this study showed data for de-rating down to approximately $70 \%$ of original engine power rating).

For MSD and slow speed diesel (SSD) engines most data within literature appear to be collected from engines tuned for their maximum rated load for continuous service. There is an inverse relationship between engine load and BC emissions (Kasper et al., 2007; MAN-Diesel-SE, 2007; Petzold et al., 2011a; Petzold et al., 2010; Ristimaki et al., 2010). A reanalysis of the BC data from Lack et al. (2008b) (using the cubic function between engine load and speed to calculate engine loads, (speed $\alpha$ engine load ${ }^{3}$ )) also show this inverse relationship for 101 vessels. In contrast, some studies that show a direct relationship between engine load and BC emissions (Cappa et al., 2012; Jayaram et al., 2011). Figure 2 (and Table 1) show all data of BC emissions and engine load available (we note that some data may exist that is not accessible to us), all of which are normalized to a $\mathrm{BC}$ emission factor $\left(E_{B C}\right)$ of $1 \mathrm{~kg}^{-1}$ at $85-100 \%$ engine load - typical of in-service maximum engine loads at unrestricted cruise speeds. (Note: Normalization to typical unrestricted cruise speeds allows all data to be compared). The average and 10 and 90 percentiles $^{1}$ for all data (SSD and MSD marine engines) are also shown and forms the basis of further analysis (red lines Fig. 3).

To better illustrate the $\mathrm{BC}$ emissions changes in an environmental context under varying engine conditions we calculate the absolute emissions of $\mathrm{BC}$ for a nautical mile of travel. Fuel consumption $\left(\mathrm{F}_{\mathrm{Cons}}\right.$; kilograms of fuel per nautical mile of travel) is calculated (Eq. 1) based on the specific fuel consumption relationship to load (Eq. 2) presented by the US EPA (2000) and is estimated for an engine with a rated power $\left(P_{\mathrm{MW}}\right)$ of $70 \mathrm{MW}$ and a rated speed of 25 knots

\footnotetext{
${ }^{1}$ For calculation of average and 10th-90th percentile, data were binned using central engine load values $(10,25,50,65,75,85$ and $100 \%$ ), interpolated to 99 points from $1-100 \%$ load and then smoothed using a 11-point running smooth function.
} 
Table 1. Studies on the effect of engine load on BC emissions found in literature.

\begin{tabular}{lllll}
\hline Study (\#) & Engine Type & Fuel Type & Measurement & Reference \\
\hline $1-6$ & MSD & HFO, LFO & EC - TOA, BC-FSN & Ristimaki et al. (2010) \\
$7-12,22-27$ & MSD & HFO, MGO, Biodiesels & BC - Filter, EC - TOA & Petzold et al. (2011a) \\
13 & MSD & HFO & EC - TOA & Petzold et al. (2004) \\
14 & MSD & HFO & EC - TOA, BC - Filter & Petzold et al. (2010) \\
15 & MSD & MDO & BC - PAS & Cappa et al. (2012) \\
16 & SSD & HFO, MDO & EC - TOA & Kasper et al. (2007) \\
17 & SSD & HFO & EC - TOA & Agrawal et al. (2010) \\
18 & SSD & HFO & EC - TOA & Agrawal et al. (2008) \\
$19-21$ & MSD & Biodiesel & EC - TOA & Jayaram et al. (2011) \\
22 & SSD, MSD & HFO, MDO, MGO & BC - PAS & Lack et al. (2008b) \\
23,24 & MSD & HFO, MGO & EC - TOA & MAN-Diesel-SE (2007) \\
$31-38$ & MSD & HFO & BC - FSN & Sarvi et al. (2008a, b) \\
39,40 & MSD & MDO & BC - FSN & Sarvi et al. (2008b) \\
\hline
\end{tabular}
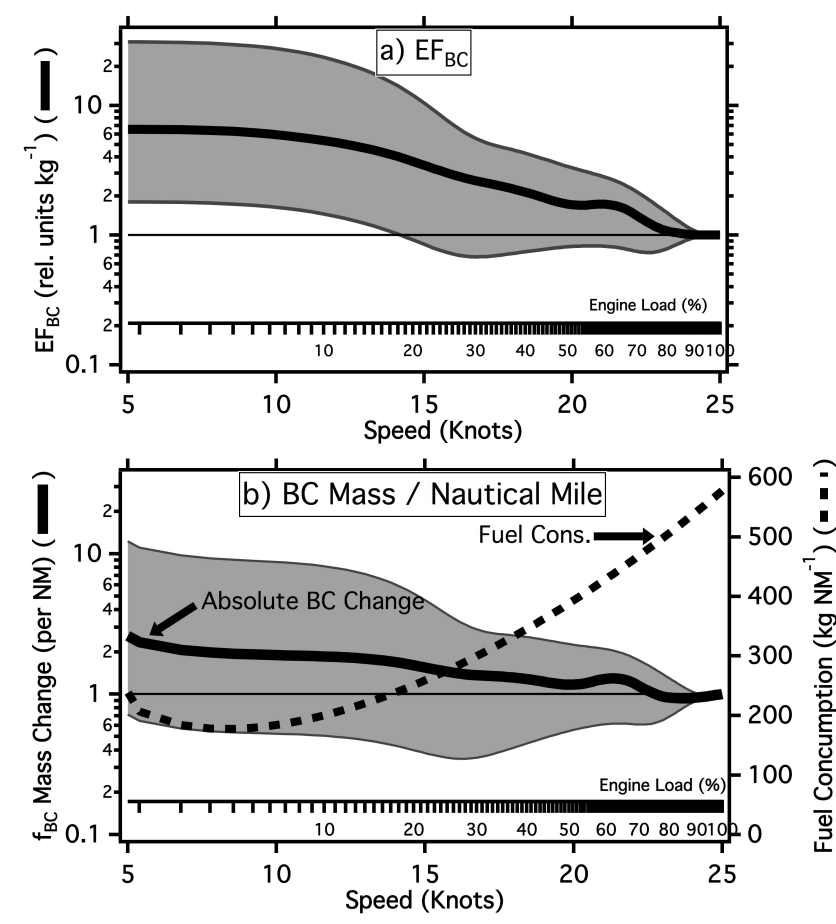

Fig. 3. (a) Average $\mathrm{EF}_{\mathrm{BC}}$ change with ship speed and engine load (with 10th and 90th percentiles) and (b) the potential absolute changes in $\mathrm{BC}$ emissions with ship speed and engine load (with 10th and 90th percentiles). $\mathrm{EF}_{\mathrm{BC}}$ data from (a) combined with fuel consumption data from (b) (circle points) to produce data in (b). All but $\mathrm{F}_{\mathrm{Cons}}$ are normalized to 1 at $100 \%$ load.

(example taken from Lack et al., 2011). $F_{\text {Cons }}$ is shown as the black dashed line in Fig. 3.

$\mathrm{F}_{\text {Cons }}\left(\mathrm{kg} \mathrm{NM}^{-1}\right)=\frac{\left(\mathrm{F}_{\text {Cons-kWhr }} \times 1000 P_{\mathrm{MW}}\right) \times \mathrm{f}_{\text {Load }}}{v_{\text {vessel }}}$
$\mathrm{F}_{\text {Cons-kWhr }}\left(\mathrm{kg}(\mathrm{kW} \cdot \mathrm{hr})^{-1}\right)=0.0142 \times\left(\frac{1}{\mathrm{f}_{\text {Load }}}+0.195\right)$

Using the average $\mathrm{EF}_{\mathrm{BC}}$ with fractional engine load ( $\mathrm{f}_{\text {Load }}$ ) and the $\mathrm{F}_{\mathrm{Cons}}$, the net per-nautical-mile $\mathrm{BC}$ mass emissions is presented in Fig. 3 which shows that, on average absolute emissions of BC per mile do not change significantly at loads between 50 to $100 \%$. Above $\sim 50 \%$ main engine load the reduced fuel consumption offsets potential increases in the $\mathrm{EF}_{\mathrm{BC}}$. Below $25 \%$ load absolute $\mathrm{BC}$ emissions may increase by $50-100 \%$. The exact behavior results from a balancing between the increase in $\mathrm{EF}_{\mathrm{BC}}$ and decrease in $\mathrm{F}_{\mathrm{Cons}}$ with decreasing ship speed. This assessment is critically dependent on the $\mathrm{EF}_{\mathrm{BC}}$ used and thus highlights the uncertainty associated with relationship between BC emissions and ship speed, and the need for more measurements. Importantly, these estimates do not adjust for potential de-rating conditions; in other words, the $\mathrm{EF}_{\mathrm{BC}}$ from these studies and the calculated average are from measurements on engines that were tuned for operation at maximum loads.

\subsection{Example of effect of engine load}

In 2007 the AP Moller-Maersk ${ }^{2}$ shipping company implemented a systematic management system for reducing ship speed in an effort to reduce fuel consumption, vessel idle time and emissions. Based on changes in main engine load across the fleet average main engine load has decreased from $60 \%$ to $35 \%$ of maximum engine rating realizing measurable reductions in fuel consumption and $\mathrm{CO}_{2}$ emissions (deKat, 2011) (Fig. 4). To assess potential BC changes we define two scenarios. The first scenario is where no engines were re-tuned across the time period. Using the average BC

\footnotetext{
${ }^{2}$ Data were obtained from certain commercial organizations mentioned in this review. This does not represent an endorsement or disapproval of that or any other organization.
} 


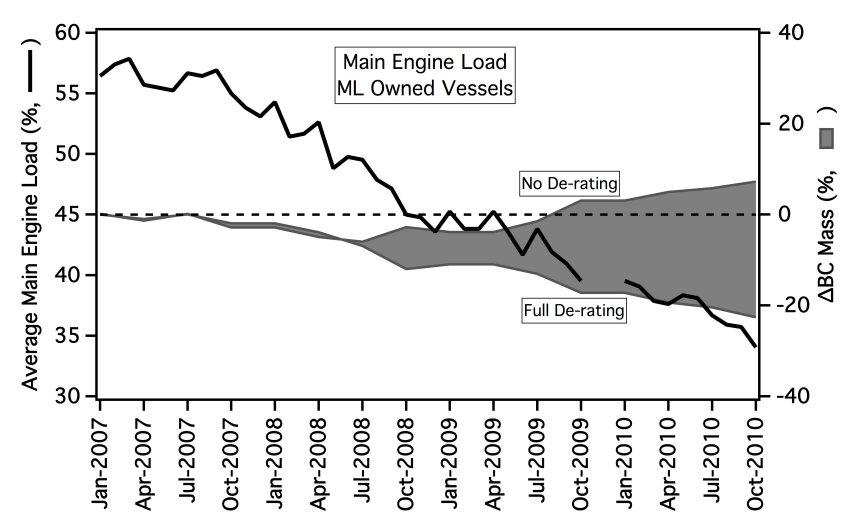

Fig. 4. Average main engine load change for the Maersk fleet (black line). Reproduced with permission from AP Moller-Maersk (deKat, 2011). The potential range of $B C$ mass changes due to the Maersk speed reduction program is also shown as the shaded region.

mass change from Sect. 3.1, Fig. 3b, BC emissions could have increased by up to $7 \%$ for the load changes reported. This is shown in Fig. 4 as the high range of the shaded area. The alternative scenario is where all engines are re-tuned to the lower load. Under this scenario BC emissions are linearly correlated to fuel consumption and could have decreased by over $20 \%$ (low range of the shaded are in Fig. 4). This example highlights the importance of ensuring engines are tuned for the dominant load characteristics to minimize BC emissions. In actuality, the "vessels comprising that figure (Fig. 4) present a mix of de-rated [re-tuned] and non-de-rated engines" (J. deKat, personal communication, 2011). It is therefore difficult to assess the actual change in BC emissions without direct measurements. However, if the operators retuned even some of the engines, then Fig. 4 suggests that BC emissions likely declined as a result of the Maersk speed reduction program.

\subsection{Regional effect of engine load - arctic fleet}

The Arctic environment is particularly sensitive to BC both in the atmosphere and when deposited on snow and ice (Quinn et al., 2008). As sea ice extent declines the possibility of more Arctic shipping traffic increases as resource exploration/extraction and full Arctic ship transits become possible. Ships, therefore, may represent an increasing local source of Arctic pollution (Corbett et al., 2010a). In addition to emissions from local ship traffic, BC emissions from ships as far South as $40^{\circ} \mathrm{N}$ may impact the Arctic climate (IMO, 2010a). To understand how shipping activities in the Arctic may contribute to $\mathrm{BC}$ emissions and how this may change with ice conditions we must have some sense for the current and potential future operating conditions (i.e. engine load at different ice conditions) of ships in that region.

Based on review of literature there are three possible engine load conditions under which a ship may operate in Arctic waters; (i) where up to $100 \%$ of engine load may be re-
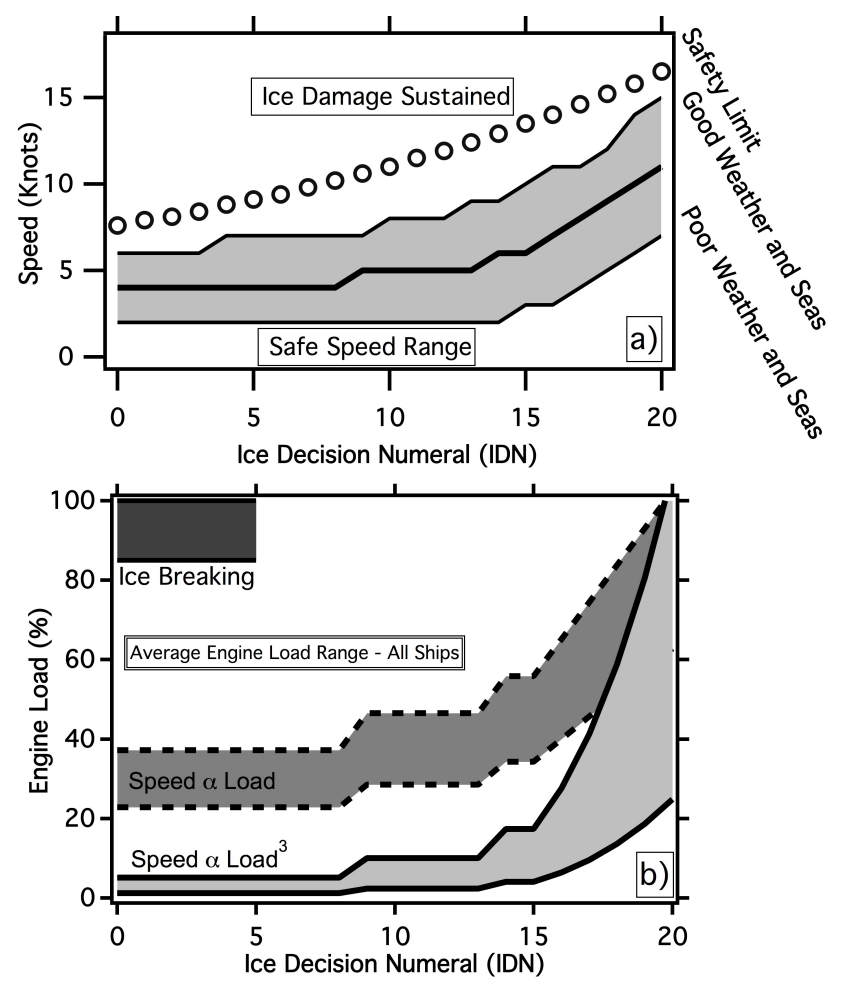

Fig. 5. (a) Ice Decision Numeral relationship to safe ship speeds in the Arctic. Reproduced from the data from Table 6 of McCallum (1996). Shaded area is standard deviation of data from multiple ships and different ship classes. (b) The estimated engine load characteristics of all ship types currently operating in the Arctic, as a function of IDN. Average speed/IDN and high speed/IDN relationship presented.

quired to break ice and maintain a minimum forward motion (IMO, 2012c): (ii) where ship hull resistance is dictated by water only and speed $\alpha$ engine load ${ }^{3}$ (MAN, 2004), although the vessel may be required to slow in response to various conditions (no ice breaking or moving) and (iii) an intermediate condition between (i) and (ii) where ships may invest energy into breaking or moving ice but faster than minimum speeds are possible. For this intermediate condition we apply a speed $\alpha$ load relationship. We investigate these three conditions further below.

The study by McCallum (1996) showed that ships in the Arctic are speed limited according to ice conditions and ship construction. Safe Arctic travel speeds through varying ice conditions are determined by the ice decision numeral (IDN), a number that scales from $0-20$ (i.e. IDN of $0=$ very thick ice/no travel possible, IDN of $20=$ very limited ice/open water travel) (Timco et al., 2005). McCallum (1996) produced an IDN framework for the Canadian Arctic using historical speed data from class A (smaller support ships) and class B ships (larger, cargo carrying) (Fig. 5a). The Arctic marine shipping assessment (AMSA, 2009) identified the maximum 
Table 2. Average Design Speed of Ships Operating in the Arctic (AMSA, 2009).

\begin{tabular}{ll}
\hline Reporting Category & $\begin{array}{l}\text { Average At-Sea Design Speed } \\
{[\text { knots] (\# of ships) }}\end{array}$ \\
\hline Bulk Carrier & $14(99)$ \\
Container & $15(321)$ \\
General Cargo & $14(248)$ \\
Government/Icebreakers & $17(67)$ \\
Passenger & $16(147)$ \\
Special Purpose & $11(14)$ \\
Tanker & $13(174)$ \\
Tug and Barge & $10(11)$ \\
Unknown & $14(396)$ \\
& Average Speed: 14 \\
& (Total Ships: 1477) \\
\hline
\end{tabular}

* Note: Fishing vessels are not included here due to the difference in operation compared to merchant ships.

rated speeds for ships currently operating in the Arctic (Table 2).

In Fig. 5b we show estimated engine loads under the three different scenarios mentioned above. Ice breaking and minimal forward motion (scenario (i) would occur with IDNs around $0 \pm 5$. Under these conditions ships may operate engines at very high engine loads $(85-100 \%)$ despite travelling at a minimal speed (IMO, 2012a, b, c) (see Fig. 5b, black shaded region). If this high load is maintained then BC emissions are optimized low. However if ice conditions vary then these high loads may be part of a duty cycle between ice breaking activity and lower load operation, resulting in increases in $\mathrm{BC}$ emissions (based on Fig. 3b).

By combining the safe speed/IDN data (Fig. 5a) and the rated speed data (Table 2) we can offer some insights into the operating load of non-ice breaking ships operating in the Arctic with varying sea ice conditions. Here we convert the safe speed/IDN data (Fig. 5a) and the rated speed data (Table 2) (using the speed - load relationships discussed in scenarios (ii) and (iii) above) to engine load. For scenario (ii) ship speed and engine load follow a cubic function as would be expected for ideal cruising conditions. For scenario (iii) we assign a linear relationship between engine load and speed, suggesting that at low speeds Arctic vessels are investing engine energy into breaking and moving ice as well as forward movement. This serves to construct a bounding range of expected relationships between speed and load, pending additional empirical data for Arctic ship operations.

Figure $5 \mathrm{~b}$ shows that, based on historical average speeds, ships operating in the Arctic are running at loads between $10 \%$ (speed $\alpha$ load $^{3}$, light grey) and $40 \%$ (speed $\alpha$ load, dark grey) for IDN up to approximately 16 . Although a specific IDN is difficult to represent visually (depending on ship class, ice type and ice surface coverage), waters with thinner and fragmented ice with more than $70 \%$ open water would have an IDN of $\sim 11$ for class B ship and an IDN of $\sim 17$ for class A ships (Timco and Johnson, 2003). For conditions of IDN $<=16$ the average BC emissions are $30-100 \%$ larger (using data from Fig. 3b) than they would be under maximum load assuming the engines are not re-tuned for the lower engine loads.

We point out that this analysis is based on the limited historical data and that as ice conditions change, future Arctic ships may not have the same speed, engine or design configurations as the current Arctic fleet. For example, Somanathan et al. (2009) predicted, for an Arctic-class cargo vessel, an average operating load of $75 \%$ using the IDN system for 1999-2003 North West Passage ice conditions. Eide et al. (2010) predicted the range of speeds across the Arctic in 2030 for an Arctic-class cargo vessel and estimated that high speeds (approx. $75-100 \%$ load) would be possible for almost all of an Arctic transit through the Northern Sea Route. Polar and North West Passage transits for the same vessel would span loads from approximately $10-100 \%$ with the lower load range required for approximately $20-50 \%$ of the distance of the transit.

It is apparent from the available data that ships currently operating in the Arctic will have highly variable engine load profiles, due to ice conditions and ship activity. If engine load profiles are indeed so variable, predicting how de-rating or speed limits may affect BC emissions is difficult for Arctic operations. It is apparent that for ships operating in the Arctic that are not involved in ice-breaking activities, engine loads are $\leq 40 \%$ and as such BC emissions are larger than they otherwise would be for a re-tuned engine or an engine operating at higher loads.

\section{Fuel quality}

The effect of fuel quality or speed on $\mathrm{BC}$ emissions is more complex than fuel-emissions relationships for other shipping emissions. In this section we investigate the effect of fuel quality on $\mathrm{BC}$ emission factors. Given that all regulations on fuel quality are currently motivated by reductions in $\mathrm{SO}_{2}$ and particulate sulfate, is there a co-benefit reduction in $\mathrm{BC}$, or an unintended increase?

\subsection{Literature review}

The relationship between sulfur emissions and fuel quality is explicitly understood. $\mathrm{SO}_{2}$ emissions are directly related to $F_{S}$ (e.g. Williams et al., 2009) and primary particulate sulfate is linked to $F_{S}$ and engine load (Lack et al., 2009; Petzold et al., 2010). However the impacts of fuel quality on some emissions is unknown or there have been relatively few studies performed. Recently, it has been observed that better quality fuels (i.e., processed distillates versus residual blends) reduce particulate sulfate and organic particles from unburned lubricating oil and fuel (Lack et al., 2011; Lack et al., 2009). 
Table 3. Studies on the effect of fuel quality found in literature.

\begin{tabular}{|c|c|c|c|c|c|c|c|c|}
\hline \multirow{2}{*}{$\begin{array}{l}\text { Study (\#) } \\
1\end{array}$} & \multicolumn{3}{|c|}{$\begin{array}{c}\text { Low Quality Fuel } \\
\text { Type, } F_{S}(\%) \text {, Ash (\%) }\end{array}$} & \multicolumn{2}{|l|}{$\begin{array}{c}\text { High Quality Fuel } \\
\text { Type, } F_{S}(\%) \text {, Ash (\%) }\end{array}$} & & \multirow[t]{2}{*}{ Measurement Type } & \multirow{2}{*}{$\begin{array}{l}\text { Reference } \\
\text { MAN-Diesel-SE (2010) }\end{array}$} \\
\hline & $\mathrm{HFO}$ & 2.2 & 0.03 & MGO & $<0.01$ & $<0.01$ & & \\
\hline 2 & $\mathrm{HFO}$ & 0.9 & 0.02 & LFO & $<0.05$ & $<0.01$ & $\mathrm{EC}-\mathrm{TOA}$ & Ristimaki et al. (2010) \\
\hline 3 & $\mathrm{HFO}$ & 0.9 & 0.02 & LFO & $<0.05$ & $<0.01$ & $\mathrm{BC}-\mathrm{FSN}$ & Ristimaki et al. (2010) \\
\hline 4 & $\mathrm{HFO}$ & 2.4 & 0.07 & LFO & $<0.05$ & $<0.01$ & $\mathrm{EC}-\mathrm{TOA}$ & Ristimaki et al. (2010) \\
\hline 5 & $\mathrm{HFO}$ & 2.4 & 0.07 & LFO & $<0.05$ & $<0.01$ & $\mathrm{BC}-\mathrm{FSN}$ & Ristimaki et al. (2010) \\
\hline 6 & $\mathrm{HFO}$ & 2.2 & 0.02 & MDO & 0.1 & 0.001 & BC - Filter & Petzold et al. (2011a) \\
\hline 7 & $\mathrm{HFO}$ & 2.2 & 0.02 & Biodiesel - Palm Oil & $<0.01$ & 0.002 & BC - Filter & Petzold et al. (2011a) \\
\hline 8 & HFO & 2.2 & 0.02 & Biodiesel - Animal Fat & $<0.01$ & 0.002 & BC - Filter & Petzold et al. (2011a) \\
\hline 9 & $\mathrm{HFO}$ & 2.2 & 0.02 & Biodiesel - Soya Bean & $<0.1$ & $<0.001$ & BC - Filter & Petzold et al. (2011a) \\
\hline 10 & $\mathrm{HFO}$ & 2.2 & 0.02 & Biodiesel - Sunflower Oil & $<0.01$ & $<0.001$ & BC - Filter & Petzold et al. (2011a) \\
\hline 11 & $\mathrm{HFO}$ & 2.2 & 0.02 & MDO & 0.1 & 0.001 & $\mathrm{EC}-\mathrm{TOA}$ & Petzold et al. 92011a) \\
\hline 12 & $\mathrm{HFO}$ & 2.2 & 0.02 & Biodiesel - Palm Oil & $<0.01$ & 0.002 & $\mathrm{EC}-\mathrm{TOA}$ & Petzold et al. (2011a) \\
\hline 13 & $\mathrm{HFO}$ & 2.2 & 0.02 & Biodiesel - Animal Fat & $<0.01$ & 0.002 & $\mathrm{EC}-\mathrm{TOA}$ & Petzold et al. (2011a) \\
\hline 14 & $\mathrm{HFO}$ & 2.2 & 0.02 & Biodiesel - Soya Bean & $<0.1$ & $<0.001$ & $\mathrm{EC}-\mathrm{TOA}$ & Petzold et al. (2011a) \\
\hline 15 & $\mathrm{HFO}$ & 2.2 & 0.02 & Biodiesel - Sunflower Oil & $<0.1$ & $<0.001$ & EC - TOA & Petzold et al. (2011a) \\
\hline $16,17^{\mathrm{a}}$ & HFO & 3.15 & 0.07 & MDO & 0.07 & $<0.01$ & $\mathrm{rBC}$ & Lack et al. (2011) \\
\hline 18,19 & HFO & 0.83 & 0.04 & MGO & 0.1 & $<0.01$ & $\mathrm{BC}-\mathrm{FSN}$ & Sarvi et al. (2008b) \\
\hline
\end{tabular}

a Includes effects of engine load changes.

These organic particles contain large molecular weight aromatic hydrocarbons and may cause significant health effects (Marin-Morales et al., 2009). Lack et al. (2011) also suggest that $\mathrm{BC}$ emissions decline as fuel quality improves.

A review of literature reporting on the effect of fuel quality on $\mathrm{EF}_{\mathrm{BC}}$ is shown in Table 3 and Fig. 6. These studies include $\mathrm{EF}_{\mathrm{BC}}$ measurements from in-use marine engines, full, and reduced size test bed engines and provide converging evidence that improved fuel quality is linked to reductions in $\mathrm{EF}_{\mathrm{BC}}$ for marine diesel engines. This is consistent with the wellunderstood relationship between fuel quality and $\mathrm{EF}_{\mathrm{BC}}$ for on-road diesel engines (Maricq, 2007). Figure 6a shows the ratio between $\mathrm{EF}_{\mathrm{BC}}$ for distillate fuels $\left(\mathrm{EF}_{\mathrm{BC}}-\right.$ Distillate $)$ and the $\mathrm{EF}_{\mathrm{BC}}$ for residual fuels $\left(\mathrm{EF}_{\mathrm{BC}}-\right.$ Residual $)$ as the same engines switched fuels. A ratio $<1$ indicates a decrease in $\mathrm{EF}_{\mathrm{BC}}$, while a ratio $>1$ indicates an increase in $\mathrm{EF}_{\mathrm{BC}}$ as fuel quality improves. At $100 \%$ engine load the $\mathrm{EF}_{\mathrm{BC}}$ decreases by an average of $30 \%$ between residual and distillate fuels. $\mathrm{EF}_{\mathrm{BC}}$ reduction is at most $80 \%$ for the data presented.

There are some irregularities within the data presented that highlight the importance of careful measurement protocols. Figure 6 includes a study by an engine manufacturer (Ristimaki et al., 2010) where $\mathrm{EF}_{\mathrm{EC}-\mathrm{TOA}}$ was measured and shows a dramatic $\mathrm{EF}_{\mathrm{EC}-\mathrm{TOA}}$ increase as fuel quality improved, opposite to the majority of the trends observed in Fig. 6a. Ristimaki et al. (2010) cite heavy metal oxidation of BC as the reason for reduced $\mathrm{BC}$ emissions from residual fuel. In what is a problematic inconsistency, that study also reported filter smoke number (FSN) trends opposite to their $\mathrm{EC}_{\mathrm{TOA}}$ trends. We find that all derived $\mathrm{EF}_{\mathrm{BC}-\mathrm{FSN}}$ of Ristimaki et al. (2010) actually decrease for distillate fuel, in contrast to their mea- sured $\mathrm{EF}_{\mathrm{EC}-\mathrm{TOA}}$ (Fig. 6b). Given the acceptable correlation in absolute $\mathrm{EF}_{\mathrm{BC}-\mathrm{FSN}}$ and $\mathrm{EF}_{\mathrm{EC}-\mathrm{TOA}}$ from Fig. 1c, it is difficult to assess which of the trends is in error. When we remove the Ristimaki et al. (2010) data from the statistical analysis the average $\mathrm{EF}_{\mathrm{BC}}$ decreases $45 \%$ (at $100 \%$ load). The 10th and 90th percentile ranges do not change significantly, except for the 90th percentile range at high loads (Fig. 6b). The study of Petzold et al. (2011a) measured both $\mathrm{EF}_{\mathrm{BC}-\mathrm{Filter}}$ and $\mathrm{EF}_{\mathrm{EC}-\mathrm{TOA}} \cdot \mathrm{EF}_{\mathrm{BC}-\mathrm{Filter}}$ data show a consistent $80 \%$ decrease when shifting from residual to distillate and bio fuels. However the $\mathrm{EF}_{\mathrm{EC}-\mathrm{TOA}}$ data show 20-60\% decreases for MGO, palm oil and animal fat bio-diesel whereas the soya bean and sunflower oil biodiesel show increases in $\mathrm{EF}_{\mathrm{EC}-\mathrm{TOA}}$ of $20-50 \%$ for intermediate loads. These data suggest some inconsistency between $\mathrm{BC}_{\mathrm{Filter}}$ and $\mathrm{EC}_{\mathrm{TOA}}$ measurements. We suggest that $\mathrm{EC}_{\mathrm{TOA}}$ measurements are not as reliable measurement tool as the others reviewed here. This is possibly due to organic particle biases discussed in Sect. 2.

Specific components of the residual fuel that may be linked to $\mathrm{BC}$ formation are not clearly understood, and $\mathrm{BC}$ formation is affected by marine engine combustion conditions that may be associated with residual fuel operation. The lower concentrations of fuel sulfur, ash or high molecular weight aromatic hydrocarbons in refined fossil and biogenic fuels are responsible for an increase in combustion efficiency (American-Bureau-of-Shipping, 2001). The oxidative ability of heavy metals in decreasing $\mathrm{BC}$ production for residual fuel may be an opposing factor, however the balance of information available suggests that distillate fuels result in a decrease in $\mathrm{BC}$ emissions. 

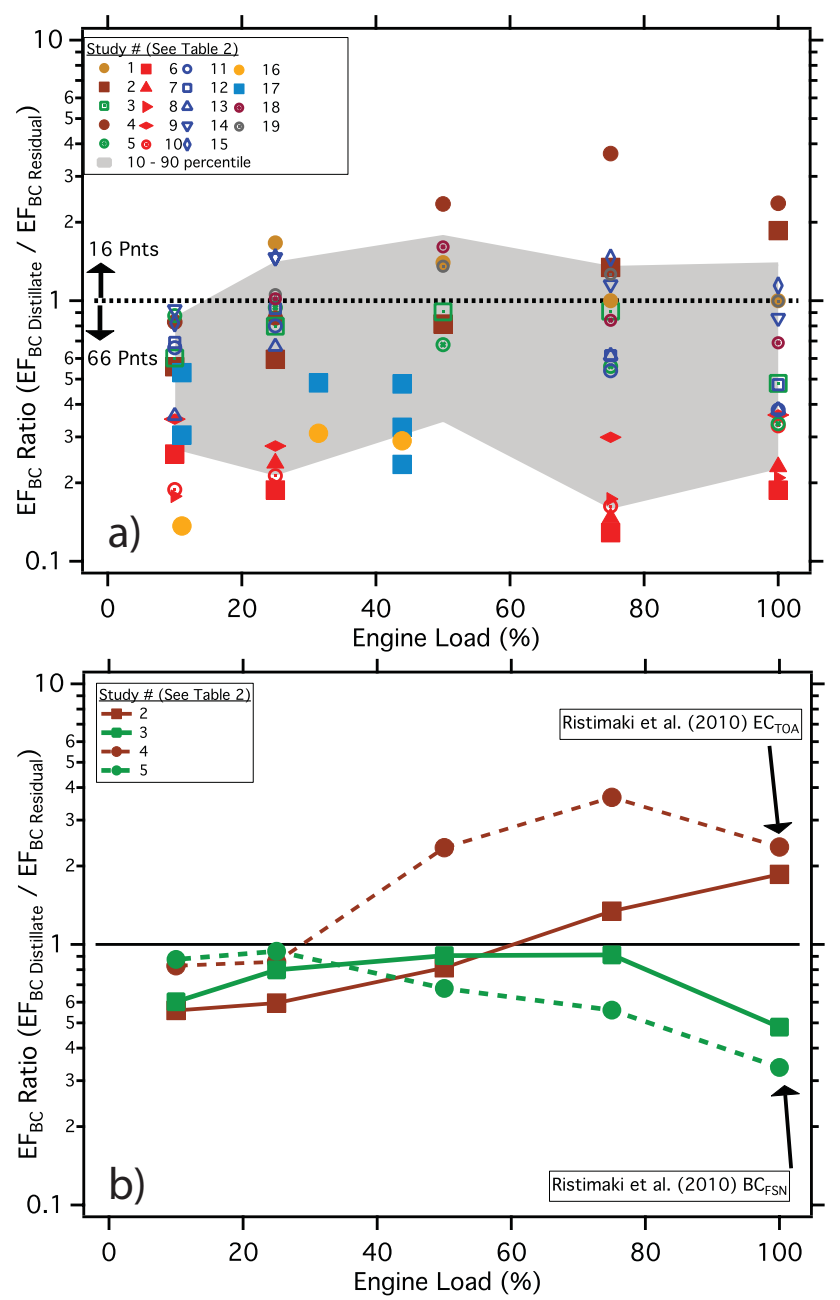

Fig. 6. (a) The change in $\mathrm{EF}_{\mathrm{BC}}$ as fuel quality improves (as a ratio between $\mathrm{EF}_{\mathrm{BC} \text {-Distillate }}$ and $\left.\mathrm{EF}_{\mathrm{BC}-\text { Residual }}\right)$. 10th-90th percentile range of data shown as shaded region, (b) Illustration of measurement inconsistency.

We also note that the effect of speed on $\mathrm{EF}_{\mathrm{BC}}$ emissions was removed from the Lack et al. (2011) data (see Appendix Fig. A1 and text for details). The $\mathrm{EF}_{\mathrm{BC}}$ before and after this correction is included in Fig. 6 .

\subsection{Evidence from field measurements}

A link between fuel quality (using $F_{S}$ as a proxy) and $\mathrm{EF}_{\mathrm{BC}}$ is evident within the data of Lack et al. (2008b) and Buffaloe et al. (2012). In the waters off California, $F_{S}$ is regulated to $<0.5 \%$ for marine distillate oil (MDO) and $<1.5 \%$ for marine gas oil (MGO) (CARB, 2009a). Buffaloe et al. (2012) measured $\mathrm{EF}_{\mathrm{BC}}$ for 41 ships in compliance with the Californian $F_{S}$ regulations $\left(F_{S}=0.4 \pm 0.3 \%\right.$, average load $=10 \pm 5 \%$ ). These $\mathrm{EF}_{\mathrm{BC}}$ data are $57 \%$ lower than the $\mathrm{EF}_{\mathrm{BC}}$ measured by Lack et al. (2008b) in the Gulf of Mexico and Houston where no $F_{S}$ regulations exist (40 ships,

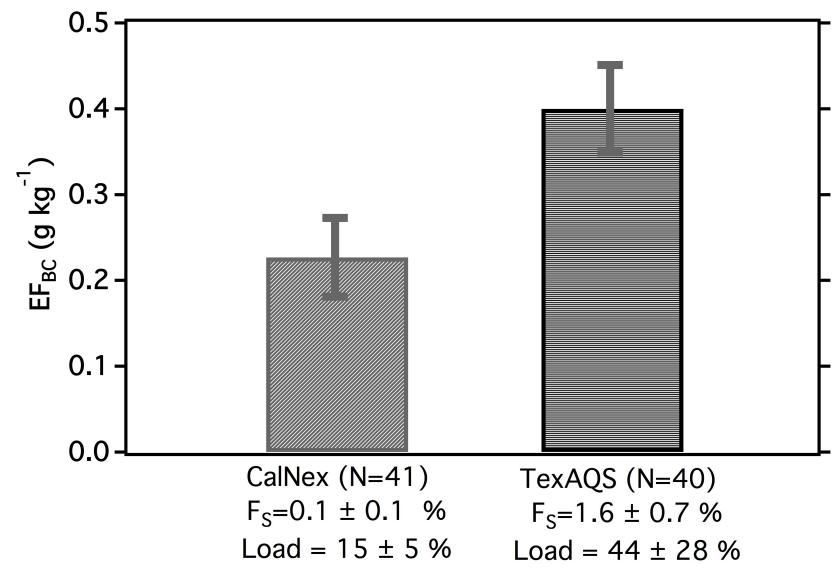

Fig. 7. $\mathrm{EF}_{\mathrm{BC}}$ (for SSD ships) in the California and the Gulf of Mexico/Houston coastal areas (Buffaloe et al., 2012).

$\mathrm{F}_{\mathrm{S}}=1.6 \pm 0.7 \%$, load $\left.=44 \pm 28 \%\right)($ Fig. 7). If we consider the trend of increased $\mathrm{EF}_{\mathrm{BC}}$ with engine load from Sect. 3, we might expect, ignoring any competing factors, that $\mathrm{BC}$ emissions from California would be higher than for Texas. That $\mathrm{EF}_{\mathrm{BC}}$ are lower for California is suggestive of a link between $\mathrm{EF}_{\mathrm{BC}}$ and fuel quality. We suspect that the variability in vessel and engine type and operating conditions in the field study of Lack et al. (2009) swamped the ability to observe a link between $\mathrm{EF}_{\mathrm{BC}}$ and $\mathrm{F}_{\mathrm{S}}$.

\section{Efficacy of scrubbers for BC removal}

Exhaust scrubbing technology can be applied to marine diesel engines to reduce emissions, particularly gas phase emissions of $\mathrm{SO}_{\mathrm{x}}, \mathrm{NO}_{\mathrm{x}}$. With a scrubber onboard, a ship can continue to consume high $\mathrm{F}_{\mathrm{S}}$ (i.e. lower cost) fuel and yet comply with $F_{S}$ regulations (e.g. Hamworthy, 2011). Scrubbers can use wet or dry physical scrubbing or chemical adsorption to remove combustion products. Removal of particles is possible however the removal rates by species are uncertain. What is the scrubbing efficacy of BC particles? How do $\mathrm{BC}$ removal rates compare to the effect of shifting from residual to distillate fuels?

\subsection{Literature review}

Current studies show scrubbers to be efficient at reducing the mass of PM emissions from anywhere from 25 to $98 \%$ (Kircher, 2008; Marine-Exhaust-Solutions, 2006; Ritchie et al., 2005; Andersson and de Vries, 2009). These estimates are based on different particle mass diameter cut offs $(<=1$, 2.5 or $\left.10 \mu \mathrm{m}\left[\mathrm{PM}_{1}, \mathrm{PM}_{2.5}, \mathrm{PM}_{10}\right]\right)$. Despite the potential to remove a large amount of total particle mass, there is uncertainty as to their effectiveness for smaller BC particles for three reasons; (i) $\mathrm{BC}$ may comprise up to $4 \%$ of $\mathrm{PM}$ mass from shipping (including hydrated sulfate) (Lack et al., 2009); (ii) BC from ship exhaust is usually associated with 


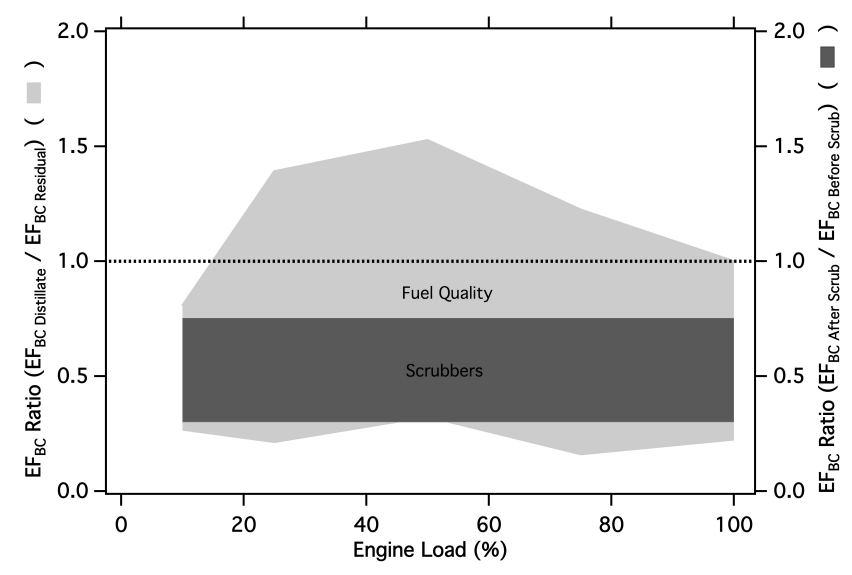

Fig. 8. Comparison of the range of $\mathrm{EF}_{\mathrm{BC}}$ changes due to fuel quality improvement (grey) and exhaust scrubbing (black).

particles having mass median diameters of $\leq 0.2 \mu \mathrm{m}$ (Lack et al., 2011; Lack et al., 2009; Petzold et al., 2011a); and (iii) The wet scrubbing efficiency for $\mathrm{BC}$ is uncertain because $\mathrm{BC}$ particles in engine exhaust can be hydrophobic or hydrophilic, depending on the mixing state and water uptake ability of co-emitted species.

In a review of sea water scrubbing efficacy Corbett et al. (2010b) concluded that $\mathrm{PM}_{2.5}$ removal was likely $75 \pm 15 \%$ and inferred from this review (mostly from the measurements from Ritchie et al., 2005) that BC removal was likely $40(+10,-15) \%$. The study of Ritchie et al. (2005) showed that the PM reductions for the scrubber used were $98 \%$ for $\mathrm{PM}_{2}, 74 \%$ for $\mathrm{PM}_{1.5}, 59 \%$ for $\mathrm{PM}_{1}$ and $45 \%$ for $\mathrm{PM}_{0.05}$. Given the common mass median diameter range for BC $(0.2 \mu \mathrm{m})$, a likely BC scrubbing efficiency of around $45-50 \%$ is inferred from these results. Andersson and de Vries (2009) ${ }^{3}$ showed $\mathrm{EC}_{\mathrm{TOA}}$ reductions of $55 \%$ for low sulfur diesel and $70 \%$ for $1.5 \% \mathrm{~F}_{\mathrm{S}}$ diesel, indicating a potential increase in scrubbing efficiency when the higher $F_{S}$ fuel is used. This can be explained by the formation of hygroscopic particulate sulfates that are internally mixed with the BC. It must be noted that Andersson and de Vries (2009) used a light duty diesel engine and fuel doped with an organic sulfur compound to produce the high sulfur fuel. Based on current studies, scrubbers can remove $\mathrm{BC}$ from the exhaust of marine diesel engines between 25-70\%, dependent on $\mathrm{F}_{\mathrm{S}}$ and scrubber design (shown in Fig. 8 as dark shaded bar in comparison to the effects of fuel quality changes on $\mathrm{EF}_{\mathrm{BC}}$ ). There is no data showing scrubber $\mathrm{BC}$ removal rates as a function of engine load and so we assume constant removal for illustrative purposes. This removal rate is within the ranges presented for fuel switching from residual to distillate fuels, and $\mathrm{BC}$ control may be more consistently effective across transient engine loads.

\footnotetext{
${ }^{3}$ Report and data used with permission from Sustainable Maritime Solutions
}

\section{Implications for regulation}

Evaluation of literature data on the emissions of $\mathrm{BC}$ from marine diesel engines (Swects. 3, 4, and 5) allows us to assess the effects of current or potential regulation on ships. For example, ship speed reductions can reduce fuel consumption and some emissions significantly. Many shipping companies are using ship speed reductions to reduce fuel consumption and costs. Will a ship speed regulation provide any benefit by locking in the voluntary speed reductions already taking place? Fuel sulfur limits are regulated in certain regions of the word to reduce the negative air quality impacts of ship emissions. Stricter global regulations will come into force within a few years. Will these regulations effectively reduce $\mathrm{BC}$ emissions, without other measures like re-tuning engines? The concern of the sensitivity of the Arctic environment to a potential increase in shipping has triggered discussions on possible regulatory action for that region. What might the best regulatory actions be for reducing, or minimizing the emission of $\mathrm{BC}$ in the Arctic?

\subsection{Ship engine load and black carbon}

Regulations of ship speed for reductions in fuel consumption may be accompanied by increases in BC unless automatic tuning or engine de-rating are employed. When ships reduce load from $100 \%$ to $25 \%$ without retuning the engine, an increase in $\mathrm{EF}_{\mathrm{BC}}$ of a factor of 3 occurs. At loads $<25 \% \mathrm{EF}_{\mathrm{BC}}$ increase significantly (up to 6.5 times). This $\mathrm{EF}_{\mathrm{BC}}$ increase is a result of when engines are operated at a loading condition outside of the tuned load. When the $\mathrm{EF}_{\mathrm{BC}}$ increases are combined with the reduced fuel consumption associated with lower loads, absolute emissions of BC increase by $15-40 \%$ down to $25 \%$ load. Below $25 \%$ load, absolute emissions of BC increase by $100-150 \%$.

Technology is emerging on newer ships where electronically controlled engines can be optimally tuned in real time for the current load (between 30 and 100\% load, Brown, 2009). In addition, engines can be re-tuned for operation at specific loads (Wettstein and Brown, 2008). Under these optimal tuning conditions fuel efficiency is maximized and it is likely that $\mathrm{EF}_{\mathrm{BC}}$ would remain approximately constant across a wide load range. Assuming an optimum $\mathrm{EF}_{\mathrm{BC}}$ across all loads (i.e. $\mathrm{EF}_{\mathrm{BC}}$ of unity: using the convention of $\mathrm{EF}_{\mathrm{BC}}$ at $100 \%$ load $=1$ ) absolute $\mathrm{BC}$ reductions equivalent of the fuel savings are achievable.

De-rating or investment in automatic tuning to achieve these $\mathrm{BC}$ reductions are likely to be motivated by regulations on ship speed, where a ship operator has certainty that an engine will be operated within a specific range of reduced load. If ship speed regulations were a permanent part of the regulatory environment, new ship designs could innovate to use smaller engines with maximum-load ratings appropriate for the required speed. 


\subsection{Fuel quality and black carbon}

The balance of evidence suggests that shifting from high sulfur, high ash residual fuels to low sulfur, low ash distillate fuels will decrease BC emissions. Up to $80 \%$ reductions in $\mathrm{EF}_{\mathrm{BC}}$ have been observed for such fuel quality shifts within several studies. From the data presented, an average $\mathrm{EF}_{\mathrm{BC}}$ reduction of $30 \%$ at $100 \%$ engine load is observed. It is therefore likely that $\mathrm{F}_{\mathrm{S}}$ regulations, such as those implemented in the Baltic and North Seas (IMO, 2005, 2007) and California (CARB, 2009a), and those to be introduced for North America (IMO, 2009) and globally (IMO, 2010b), will reduce BC emissions. In addition, the call by the European Parliament for the IMO to ban HFO in the Arctic (to eliminate effects of spilled fuel) is strengthened as this will likely reduce and/or minimize BC emissions in the Arctic (EU, 2011). Current regulation on fuel quality addresses $F_{S}$ only. From the reviewed literature, it was not possible to determine whether $\mathrm{F}_{\mathrm{S}}$, or another component of fuel quality, such as ash, aromatic hydrocarbon or heavy metal content, was responsible for the changes in $\mathrm{EF}_{\mathrm{BC}}$. From the data presented, we are unable to conclude if heavy metals catalyze the combustion of BC.

\subsection{Scrubbers and black carbon}

Scrubbers that reduce emissions of $\mathrm{SO}_{2}$ to levels equivalent to consuming regulatory-compliant low sulfur fuel offer an alternative to using distillate fuels. In addition to reductions in $\mathrm{SO}_{2}$ emissions, it is apparent, from the very limited data available, that BC removal by scrubbers is between $40-70 \%$, dependent on $\mathrm{F}_{\mathrm{S}}$. While more work is needed to characterize scrubber BC control efficacy across varying loads, scrubbing residual high $\mathrm{F}_{\mathrm{S}}$ fuel appears to provide similar $\mathrm{BC}$ reduction rates to switching from residual to distillate fuels.

\subsection{Regional regulatory combination: arctic shipping}

Given the sensitive eco-systems of the Arctic, careful consideration is being given to minimizing the impact of Arctic shipping. Emissions of $\mathrm{BC}$ from ships have been identified as one of a number of priority $\mathrm{BC}$ mitigation opportunities for the Arctic (Arctic-Council, 2010; Rosenthal and Watson, 2011). Distillate fuels already required in the Antarctic could become required in the Arctic for reasons unrelated to $\mathrm{BC}$ and climate forcing (e.g. elimination of residual oil spills). It is apparent, however that the use of distillate fuel may also reduce $\mathrm{BC}$ emissions, therefore providing a co-benefit for the Arctic. If Arctic shipping routes evolve into commonly used alternatives to the traditional Panama and Suez canal routes for transits from Europe to Asia and North America to Asia (e.g. Somanathan et al., 2009), activity of ships consuming residual fuels is likely to increase in the Arctic. The use of distillate fuels by these ships in the Arctic (similar to the Antarctic) would reduce $\mathrm{BC}$ emissions that would re- sult from using residual fuel. Policies requiring scrubbing of residual or distillate fuel exhaust would provide alternate or additional options for $\mathrm{BC}$ reductions.

Arctic ship speed limits might serve to reduce the probability of whale strikes, reduce navigation hazards, and will reduce some emissions (e.g. $\mathrm{CO}_{2}$ ). Ship speed-engine load relationships may be atypical under ice-safe operations compared to ice-free voyages and so it is difficult to assess the characteristics of current or future engine loads. Under ice breaking conditions engine load is likely near a maximum while ships moving slowly through loose ice flows are likely running at low engine loads and may be emitting up to twice as much BC per nautical mile of travel that is estimated using current methodologies (Corbett et al., 2010a) (assuming engines are tuned for maximum load ratings). For the next few decades it is likely that the transit paths of ships in the Arctic would encounter a variety of ice conditions (and require a range of engine load). De-rating may not be a viable option for the variability in lower loads possible. $\mathrm{BC}$ emission reduction strategies may require an automatic tuning technology or assessment of each ship's load distribution history to ensure the engine can be optimally tuned. If there is so much variability in the engine load distribution as to make a specific tuning below maximum-load rating unviable, exhaust scrubbing or consumption of higher quality fuel would be effective options for controlling BC under speed-restriction policies.

\section{Summary}

Emissions of BC are of concern from both an air quality and climate (particularly Arctic climate) perspective. The International Maritime Organization (IMO) has begun to investigate the impacts of BC emitted from shipping activity and tasked an IMO subcommittee with providing more details on the definition of $\mathrm{BC}$, measurement methods and possible strategies for BC mitigation. This review addressed the definition, measurement methods and effects of speed, fuel quality and exhaust gas scrubbing on BC emissions from ships.

We find that $\mathrm{BC}$ emission factors measured by photoacoustic, filter-based absorption (PSAP and MAAP) and laser-induced incandescence are consistent with one another on an absolute level. Corrected filter smoke number (FSN) BC also show good correlation with thermal optical reflectance-measured $\mathrm{EC}$, however the TOA method shows inconsistent results to both $\mathrm{BC}_{\mathrm{FSN}}$ and $\mathrm{BC}_{\mathrm{Filter}}$ for two studies.

$\mathrm{BC}$ emission factors increase as engine load decreases and absolute emissions of $\mathrm{BC}$ increase up to $100 \%$ at low loads when the average $\mathrm{EF}_{\mathrm{BC}}$ is combined with the reduced fuel consumption that results from reduced ship speeds.

Ships currently operating in the Arctic are likely operating at highly variable engine loads $(25-100 \%)$ due to ice conditions. If this load engine variability makes it difficult 


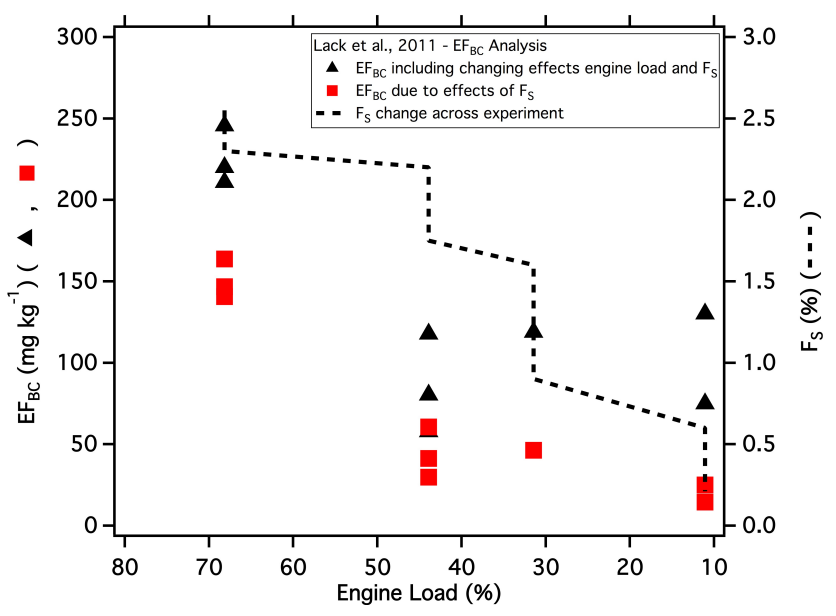

Fig. A1. $E F_{B C}$ changes with engine load (and $F_{S}$ ) from the study of Lack et al. (2011). Red data has the effects of engine load removed, using the average $\mathrm{EF}_{\mathrm{BC}}$ engine load relationship from Sect. 3 (grey line).

for engine de-rating the most effective measures for reducing BC from Arctic shipping would be through the use of exhaust scrubbing or a switch to higher quality fuel.

Based on available literature, improvements to fuel quality (from residual to distillate fuels) can reduce $\mathrm{BC}$ emissions by an average of $30 \%$ and potentially up to $80 \%$. More research is required to determine how each component of fuel quality affects BC emissions. Although data are very limited, exhaust scrubbing systems likely remove BC with an efficiency of $25-70 \%$, dependent on fuel sulfur content. More research is needed by scrubbing manufacturers to understand the removal of particulate matter by size and composition.

\section{Appendix A}

The study of Lack et al. (2011) measured $\mathrm{EF}_{\mathrm{BC}}$ changes as a large container ship switched from low to high quality fuel and slowed. Using the average $\mathrm{EF}_{\mathrm{BC}}$ with engine load relationship $\left(\mathrm{EF}_{\mathrm{BC}-\mathrm{Load}}\right)$ derived from literature data in Sect. 3, the effect of speed on $\mathrm{EF}_{\mathrm{BC}}$ emissions was removed from this data. To do this we divide the Lack et al. (2011) data at 70, 45,30 and $10 \%$ load by the normalized average $\mathrm{EF}_{\mathrm{BC}-\text { Load }}$ value for that load. The results of which are presented as the red data in Appendix Fig. 1. We then divide the average of the corrected $\mathrm{EF}_{\mathrm{BC}}$ at lower sulfur by the average $\mathrm{EF}_{\mathrm{BC}}$ at high sulfur to determine the $\mathrm{EF}_{\mathrm{BC}}$ reduction due to the change in $\mathrm{F}_{\mathrm{S}}$.
Acknowledgements. Funded by NOAAs climate program. Thanks to Christopher Cappa and Gina Buffaloe (University of California, Davis), Donald Gregory (Sustainable Maritime Solutions ${ }^{2}$ ), Jean deKat (AP Moller-Maersk ${ }^{2}$ ), and Daniel Murphy, A. R. Ravishankara and Eric Williams (NOAA) for contributing data and/or discussions.

Edited by: W. Birmili

\section{References}

Agrawal, H., Malloy, Q. G. J., Welch, W. A., Wayne Miller, J., and CockerIII, D. R.: In-use Gaseous and Particulate Matter Emissions from a Modern Ocean Going Container Vessel, Atmos. Environ., 42, 5504-5510, doi:10.1016/j.atmosenv.2008.02.053, 2008.

Agrawal, H., Welch, W. A., Henningsen, S., Miller, J. W., and Cocker III, D. R.: Emissions from Main Propulsion Engine on a Container Ship at Sea, J. Geophys. Res., 115, D23205, doi:10.1029/2009jd013346, 2010.

American-Bureau-of-Shipping: Notes on Heavy Fuel Oil: $\quad$ http://www.eagle.org/eagleExternalPortalWEB/ ShowProperty/BEARepository/News\&Events/Publications/ ABSInternationalDirectory, 2001.

AMSA: Arctic Marine Shipping Assessment 2009 Report: http://www.pame.is/images/stories/PDF_Files/ AMSA_2009_Report_2nd_print.pdf, 2009.

Andersson, J. and de Vries, S.: Results of the Evaluation of an Exhaust Scrubber: A Screening Report for Sustainable Maritime Solutions, Ricardo, UK, 33, 2009.

Andreae, M. O. and Gelencsér, A.: Black carbon or brown carbon? The nature of light-absorbing carbonaceous aerosols, Atmos. Chem. Phys., 6, 3131-3148, doi:10.5194/acp-6-3131-2006, 2006.

Arctic-Council: Final Report: Meeting of Deputy Ministers (27 May 2010): http://arctic-council.org/filearchive/ DMM27May2010FinalReport.pdf, 2010.

Arnott, W. P., Hamasha, K., Moosmuller, H., Sheridan, P. J., and Ogren, J. A.: Towards Aerosol Light-Absorption Measurements with a 7-Wavelength Aethalometer: Evaluation with a Photoacoustic Instrument and 3-Wavelength Nephelometer, Aerosol Sci. Tech., 39, 17-29, 2005.

Arnott, W. P., Walker, J. W., Moosm,ller, H., Elleman, R. A., Jonsson, H. H., Buzorius, G., Conant, W. C., Flagan, R. C., and Seinfeld, J. H.: Photoacoustic insight for Aerosol Light Absorption Aloft from Meteorological Aircraft and Comparison with Particle Soot Absorption Photometer Measurements: DOE Southern Great Plains Climate Research Facility and the Coastal Stratocumulus Imposed Perturbation Experiments, J. Geophys. Res., 111, D05S02, doi:10.1029/2005jd005964, 2006.

Bond, T. C., Anderson, T. L., and Campbell, D.: Calibration and Intercomparison of Filter-Based Measurements of Visible Light Absorption by Aerosols, Aerosol Sci. Tech., 30, 582-600, 1999.

Bond, T. C., and Bergstrom, R. W.: Light Absorption by Carbonaceous Particles: An Investigative Review, Aerosol Sci. Tech., 40, 27-67, 2006.

Boparai, P., Lee, J., and Bond, T. C.: Revisiting ThermalOptical Analyses of Carbonaceous Aerosol using a 
Physical Model, Aerosol Sci. Technol., 42, 930-948, doi:10.1080/02786820802360690, 2008.

Brown, D.: Helping Shipowners Cut Fuel Bills with Wartsila LowSpeed Engines, Wartsila Techn. J. 01, 34-37, 2009.

Buffaloe, G., Cappa, C., Williams, E., Coffman, D. J., Hayden, K., Lack, D. A., Lerner, B., Li, S.-M., Massoli, P., Nuaanman, I., Onasch, T. B., and Quinn, P. K.: Particulate Emissions from Commercial Shipping in the Califronia Fuel Quality Regulated Zone, J. Geophys. Res., in preparation, 2012.

Buhaug, Ø., Corbett, J. J., Endresen, Ø., Eyring, V., Faber, J., Hanayama, S., Lee, D. S., Lee, D., Lindstad, H., Mjelde, A., Pålsson, C., Wanquing, W., Winebrake, J. J., and Yoshida, K.: Second IMO GHG study 2009, International Maritime Organization, London, UK, 129, 2009.

Burtscher, H.: Physical Characterization of Particulate Emissions from Diesel Engines: A Review, J. Aero. Sci, 36, 896-932, doi:10.1016/j.jaerosci.2004.12.001, 2005.

Cappa, C. D., Williams, E., Buffaloe, G., Coffman, D. J., Hayden, K., Lack, D. A., Lerner, B., Li, S.-M., Massoli, P., Nuaanman, I., Onasch, T. B., and Quinn, P. K.: The Influence of Operating Speed on Gas and Particle-Phase Emissions from the R/V Miller Freeman, Environ. Sci. Technol., under review, 2012.

CARB: Final Regulation Order. Fuel Sulfur and Other Operational Requirments for Ocean-Going Vessels Within California Waters and 24 Nautical Miles of the California Baseline, California Air Resources Board, 2009a.

CARB: Vessel Speed Reduction for Ocean-going Vessels: http: //www.arb.ca.gov/ports/marinevess/vsr/vsr.htm, 2009b.

Christian, V. R., Knopf, F., Jaschek, A., and Schindler, W.: Messmethodik der Bosch-Zahl mit erhohter Empfindlichkeit, Motortech. Z., 54, 16-22, 1993.

Corbett, J. J., Winebrake, J. J., Green, E. H., Kasibhatla, P., Eyring, V., and Lauer, A.: Mortality from Ship Emissions: A Global Assessment, Environ. Sci. Technol., 41, 8512-8518, doi:10.1021/es071686z, 2007.

Corbett, J. J., Wang, H., and Winebrake, J. J.: The Effectiveness and Costs of Speed Reductions on Emissions from International Shipping, Trans. Res. D: Trans. Environ., 14, 593-598, doi:10.1016/j.trd.2009.08.005, 2009.

Corbett, J. J., Lack, D. A., Winebrake, J. J., Harder, S., Silberman, J. A., and Gold, M.: Arctic Shipping Emissions Inventories and Future Scenarios, Atmos. Chem. Phys., 10, 9689-9704, doi:10.5194/acp-10-9689-2010, 2010a.

Corbett, J. J., Winebrake, J. J., and Green, E. H.: An Assessment of Technologies for Treducing Regional Short-Lived Climate Forcers Emitted by Ships with Implications for Arctic Shipping, Carb. Manage., 1, 207-225, doi:10.4155/cmt.10.27, 2010b.

Cross, E. S., Onasch, T., Ahern, A. T., Wrobel, W., Slowik, J., Olfert, J., Lack, D. A., Massoli, P., Cappa, C. D., Schwarz, J. P., et al.: Soot Particle Studies - Instrument Inter-Comparison Project Overview, Aerosol Sci. Tech., 44, 592-611, 2010.

deKat, J.: (Super) Slow Steaming: The Maersk Experience: http://www.transportenvironment.org/events/ seminar-slow-steaming-and-speed-limits-shipping, 2011.

Eide, L. I., Eide, M. S., and Endresen, Ø.: Shipping Across the Arctic Ocean: A Feasible Option in 2030-2050 as a Result of Global Warming?: http://www.dnv.com/resources/position papers/shipping_arctic.asp, 2010.
EU: A sustainable EU policy for the High North, European Parliament, 2009/2214(INI), 2011.

Eyring, V., Kohler, H. W., van Aardenne, J., and Lauer, A.: Emissions from International Shipping: 1. The Last 50 Years, J. Geophys. Res., 110, D17305, doi:10.1029/2004JD005619, 2005.

Eyring, V., Isaksen, I. S. A., Berntsen, T., Collins, W. J., Corbett, J. J., Endresen, O., Grainger, R. G., Moldanova, J., Schlager, H., and Stevenson, D. S.: Transport Impacts on Atmosphere and Climate: Shipping, Atmos. Environ., 44, 4735-4771, 2010.

Flanner, M. G., Zender, C. S., Randerson, J. T., and Rasch, P. J.: Present-day Climate Forcing and Response from Black Carbon in Snow, J. Geophys. Res., 112, D11202, doi:10.1029/2006JD008003, 2007.

Hamworthy: Exhaust Gas Cleaning Systems, http://www. hamworthy.com/PageFiles/1774/ExhaustGasCleaningSystems. pdf, 2011.

Hansen, J. and Nazarenko, L.: Soot Climate Forcing Via Snow and Ice Albedos, Proc. Natl. Acad. Sci., 101, 423-428 doi:10.1073/pnas.2237157100, 2004.

Harvald, S.: Prediction of Power of Ships, Department of Ocean Engineering, Technical University of Denmark, Lyngby, Denmark, 1977.

IMO: New Rules to Reduce Emissions from Ships Enter Into Force: http://www.imo.org/blast/mainframe.asp?topic_id=1018 $\&$ doc_id=4884, 2005.

IMO: North Sea SECA in effect from 22 November 2007: http://www.imo.org/inforesource/mainframe.asp?topic_id= 1472\\&doc_id=8719, 2007.

IMO: Amendments to MARPOL Annex VI, Amendments to the NOx Technical Code, IMO MEPC 58, London, UK, 2008.

IMO: Proposal to Designate an Emission Control Area for Nitrogen Oxides, Sulphur Oxides and Particulate Matter. Submitted by the United States and Canada., IMO MEPC 59, 2009.

IMO: Emissions Inventory and Analysis of Impacts of Short-Lived Climate Forcing Aerosols from International Shipping Activity in the Arctic, 15th Session of the Bulk Liquids and Gases SubCommittee of the International Maritime Organisation, London, UK, 2010a.

IMO: Air Pollution from Ships Cut with Entry Into Force of MARPOL Amendments: http://www.imo.org/newsroom/mainframe. asp?topic_id=1859 \\&doc_id=13309, 2010b.

IMO: Report of the Marine Environement Protection Committee on its Sixty-Second Session, IMO MEPC 62, London, UK, 2011 a.

IMO: Definition and Measurement of Black Carbon in International Shipping, 16th Session of the Bulk Liquids and Gases SubCommittee of the International Maritime Organisation, London, UK, $2011 b$.

IMO: Resolution MEPC 203 (62). 2011 Amendments to MARPOL Annex VI: Energy Efficiency, IMO MEPC 62, London, UK, 2011c.

IMO: Development of a Mandatory Code for Ships Operating in Polar Waters: Report of the correspondence group, International Maritime Organisation: Sub-Committee on Ship Design and Equipment, 56th Session, London, UK, 2012a.

IMO: Development of a Mandatory Code for Ships Operating in Polar Waters: Proposals for the content of the Polar Water Operational Manual, International Maritime Organisation: SubCommittee on Ship Design and Equipment, 56th Session, London, UK, 2012b. 
IMO: Development of a Mandatory Code for Ships Operating in Polar Waters: Information on Compression in a Sea Ice Field, International Maritime Organisation: Sub-Committee on Ship Design and Equipment, 56th Session, London, UK, 2012c.

ISO: Petroleum Products - Fuels (class F) - Specifications of Marine Fuels; ISO 8217: 1987(E), Geneva, Switzerland, 15 April, 1987.

Jayaram, V., Agrawal, H., Welch, W. A., Miller, J. W., and Cocker, D. R.: Real-Time Gaseous, PM and Ultrafine Particle Emissions from a Modern Marine Engine Operating on Biodiesel, Environ. Sci. Technol., 45, 2286-2292, doi:10.1021/es1026954, 2011.

Kasper, A., Aufdenblatten, S., Forss, A., Mohr, M., and Burtscher, H.: Particulate Emissions from a Low-Speed Marine Diesel Engine, Aerosol Sci. Tech., 41, 24-32, 2007.

Kircher, D.: Holland America Line Sea Water Scrubber Demonstration Project. Presented at: Faster Freight, Cleaner Air Northwest Conference, Seattle, WA, USA, 2008.

Kondo, Y., Sahu, L., Kuwata, M., Miyazaki, Y., Takegawa, N., Moteki, N., Imaru, J., Han, N. S., Nakayama, T., Kim-Oanh, N. T., et al.: Stabilization of the Mass Absorption Cross Section of Black Carbon for Filter-Based Absorption Photometry by the Use of a Heated Inlet, Aerosol Sci. Tech., 43, doi:10.1080/02786820902889879, 2009.

Kondo, Y., Sahu, L., Moteki, N., Khan, F., Takegawa, N., Liu, X., Koike, M., and Miyakawa, T.: Consistency and Traceability of Black Carbon Measurements Made by Laser-Induced Incandescence, Thermal-Optical Transmittance, and Filter-Based Photo-Absorption Techniques, Aerosol Sci. Tech., 45, 295-312, doi:10.1080/02786826.2010.533215, 2011.

Lack, D., Lovejoy, E., Baynard, T., Pettersson, A., and Ravishankara, A.: Aerosol Absorption Measurement Using Photoacoustic Spectroscopy: Sensitivity, Calibration, and Uncertainty Developments, Aerosol Sci. Tech., 40, 697-708, 2006.

Lack, D. A., Cappa, C. D., Covert, D. S., Baynard, T., Massoli, P., Sierau, B., Bates, T. S., Quinn, P. K., Lovejoy, E. R., and Ravishankara, A. R.: Bias in Filter-Based Aerosol Light Absorption Measurements Due to Organic Aerosol Loading: Evidence from Ambient Measurements, Aerosol Sci. Tech., 42, 10331041, 2008a.

Lack, D. A., Lerner, B., Granier, C., Baynard, T., Lovejoy, E. R., Massoli, P., Ravishankara, A. R., and Williams, E.: Light Absorbing Carbon Emissions from Commercial Shipping, Geophys. Res. Lett., 35, L13815, doi:10.1029/2008GL033906, 2008b.

Lack, D. A., Corbett, J. J., Onasch, T. B., Lerner, B., Massoli, P., Quinn, P. K., Bates, T. S., Covert, D., Coffman, D. J., Sierau, B., et al.: Particulate Emissions from Commercial Shipping. Chemical, Physical and Optical Proprties, J. Geophys. Res., 114, D00F04, doi:10.1029/2008/JD011300, 2009.

Lack, D. A., Cappa, C. D., Langridge, J., Bahreini, R., Buffaloe, G., Brock, C., Cerully, K., Coffman, D., Hayden, K., Holloway, J., et al.: Impact of Fuel Quality Regulation and Speed Reductions on Shipping Emissions: Implications for Climate and Air Quality, Environ. Sci. Technol., 45, 9052-9060, doi:10.1021/es2013424, 2011.

Lauer, A., Eyring, V., Corbett, J. J., Wang, C., and Winebrake, J. J.: Assessment of Near-Future Policy Instruments for Oceangoing Shipping: Impact on Atmospheric Aerosol Burdens and the Earth's Radiation Budget, Environ. Sci. Technol., 43, 55925598, doi:10.1021/es900922h, 2009.
MAN: Basic Principles of Ship Propulsion, 2004.

MAN-Diesel-SE: Operation on Low-Sulphur Fuels. MAN B\&W Two-Stroke Engines, MAN B\&W, Copenhagen, 1-24, 2010.

Maricq, M. M.: Chemical Characterization of Particulate Emissions from Diesel Engines: A Review, J. Aero. Sci, 38, 1079-1118, doi:10.1016/j.jaerosci.2007.08.001, 2007.

Marin-Morales, M. A., Leme, D. M., and Mazzeo, D. E. C.: Polycyclic Aromatic Hydrocarbons: Pollution, Health Effects and Chemistry, edited by: Haines, P. A. and Hendrickson, M. D., Nova Science Publishers, 361 pp., New York, USA, 2009.

Marine-Exhaust-Solutions: Scrubber Development Beats Regulations in Environmental Stakes: http://www. marineexhaustsolutions.com/mediacentre_det.asp?id=61, 2006.

McCallum, J.: Safe Speed in Ice - An analysis of Transit Speed and Ice decision Numerals, Transport Canada, 1996.

Moosmuller, H., Chakrabarty, R. K., and Arnott, W. P.: Aerosol Light Absorption and its Measurement: A Review, J. Quant. Spectrosc. Rad. T., 110, 844-878, doi:10.1016/j.jqsrt.2009.02.035, 2009.

Moteki, N. and Kondo, Y.: Dependence of Laser-Induced Incandescence on Physical Properties of Black Carbon Aerosols: Measurements and Theoretical Interpretation, Aerosol Sci. Tech., 44, 663-675, doi:10.1080/02786826.2010.484450, 2010.

Myhre, G., Shine, K. P., Radel, G., Gauss, M., Isaksen, I. S. A., Tang, Q., Prather, M. J., Williams, J. E., van Velthoven, P., Dessens, O., Koffi, B., Szopa, S., Hoor, P., Grewe, V., Borken-Kleefeld, J., Berntsen, T. K., and Fuglestvedt, J. S.: Radiative Forcing Due to Changes in Ozone and Methane Caused by the Transport Sector, Atmos. Environ., 45, 387-394, doi:10.1016/j.atmosenv.2010.10.001, 2011.

Nakayama, T., Kondo, Y., Moteki, N., Sahu, L. K., Kinase, T., Kita, K., and Matsumi, Y.: Size-Dependent Correction Factors for Absorption Measurements using Filter-based Photometers: PSAP and COSMOS, J. Aerosol. Sci., 41, 333-343, 2010.

NOAA: Compliance Guide for Right Whale Ship Strike Reduction Rule, National Marine Fisheries Service, 2008.

Northrop, W. F., Bohac, S. V., Chin, J.-Y., and Assanis, D. N.: Comparison of Filter Smoke Number and Elemental Carbon Mass From Partially Premixed Low Temperature Combustion in a Direct-Injection Diesel Engine, Journal of Engineering for Gas Turbines and Power, 133, 102804-102806, doi:10.1115/1.4002918, 2011.

Petzold, A., Feldpausch, P., Fritzsche, L., Minikin, A., Lauer, A., and Bauer, H.: Particle Emissions from Ship Engines, European Aerosol Conference, Budapest, Hungary, http://www. scientificcommons.org/17769664, 2004.

Petzold, A., Weingartner, E., Hasselbach, J., Lauer, A., Kurok, C., and Fleischer, F.: Physical Properties, Chemical Composition, and Cloud Forming Potential of Particulate Emissions from a Marine Diesel Engine at Various Load Conditions, Environ. Sci. Technol., 44, 3800-3805, 2010.

Petzold, A., Lauer, P., Fritsche, U., Hasselbach, J., Lichtenstern, M., Schlager, H., and Fleischer, F.: Operation of Marine Diesel Engines on Biogenic Fuels: Modification of Emissions and Resulting Climate Effects, Environ. Sci. Technol., 45, 10394-10400, doi:10.1021/es2021439, 2011a.

Petzold, A., Marsh, R., Johnson, M., Miller, M., Sevcenco, Y., Delhaye, D., Ibrahim, A., Williams, P., Bauer, H., Crayford, A., Bachalo, W. D.. and Raper, D.: Evaluation of Methods for Mea- 
suring Particulate Matter Emissions from Gas Turbines, Environ. Sci. Technol., 45, 3562-3568, doi:10.1021/es103969v, 2011 b.

Port-of-San-Diego: Vessel Speed Reduction Program, San Diego, CA, USA, 2009.

PWC: A Game Changer for the Shipping Industry? An analysis of the future impact of carbon regulations on environment and industry: http://www.scribd.com/doc/68027866/ Shipping-GHG-PwC-Final, 2011.

Quinn, P. K., Bates, T. S., Baum, E., Doubleday, N., Fiore, A. M., Flanner, M., Fridlind, A., Garrett, T. J., Koch, D., Menon, S., Shindell, D., Stohl, A., and Warren, S. G.: Short-lived pollutants in the Arctic: their climate impact and possible mitigation strategies, Atmos. Chem. Phys., 8, 1723-1735, doi:10.5194/acp8-1723-2008, 2008.

Quinn, P. K., Stohl, A., Bernsten, T., Burkhart, J. F., Christensen, J., Flanner, M., Kupiainen, K., Lack, D., H., L., Shepherd, M., Shevchenko, V., Skov, H., and Vestreng, V.: The Impact of Black Carbon on Arctic Climate. AMAP Expert Group on Short-Lived Climate Forcers, 1st Assessment Report, AMAP, 2011.

Ramanathan, V. and Carmichael, G.: Global and Regional Climate Changes Due to Black Carbon, Nature Geosci., 1, 221-227, 2008.

Ristimaki, J., Hellem, G., and Lappi, M.: Chemical and Physical Characterization of Exhaust Particulate Matter from a Marine Medium Speed Diesel Engine, CIMAC Congress, Bergen, Norway, 2010.

Ritchie, A., de Jonge, E., Hugi, C., and Cooper, D.: European Commission Directorate General Environment, Service Contract on Ship Emissions: Assignment, Abatement, and Market-based Instruments. Task $2 \mathrm{c}-\mathrm{SO}_{2}$ Abatement, Entec UK Limited, Cheshire, Northwich, UK, 2005.

Rosenthal, E., and Watson, R.: Multilateral Efforts to Reduce Black Carbon Emissions: A Lifeline for the Warming Arctic?, Rev. Eur. Comm. Int. Environ. Law, 20, 3-10, doi:10.1111/j.14679388.2011.00705.x, 2011.

Sarvi, A., Fogelholm, C.-J., and Zevenhoven, R.: Emissions from Large-Scale Medium-Speed Diesel Engines: 1. Influence of Engine Operation Mode and Turbocharger, Fuel Proc. Technol., 89, 510-519, doi:10.1016/j.fuproc.2007.10.006, 2008a.

Sarvi, A., Fogelholm, C.-J., and Zevenhoven, R.: Emissions from Large-Scale Medium-Speed Diesel Engines: 2. Influence of Fuel Type and Operating Mode, Fuel Proc. Technol., 89, 520-527, doi:10.1016/j.fuproc.2007.10.005, 2008b.

Schmid, H., Laskus, L., Jorgen Abraham, H., Baltensperger, U., Lavanchy, V., Bizjak, M., Burba, P., Cachier, H., Crow, D., Chow, J., Gnauk, T., Even, A., ten Brink, H. M., Giesen, K.P., Hitzenberger, R., Hueglin, C., Maenhaut, W., Pio, C., Carvalho, A., Putaud, J.-P., Toom-Sauntry, D., and Puxbaum, H.: Results of the "carbon conference" international aerosol carbon round robin test stage I, Atmos. Environ., 35, 2111-2121, doi:10.1016/s1352-2310(00)00493-3, 2001.
Schwarz, J. P., Gao, R. S., Fahey, D. W., Thomson, D. S., Watts, L. A., Wilson, J. C., Reeves, J. M., Darbeheshti, M., Baumgardner, D. G., Kok, G. L., Chung, S. H., Schulz, M., Hendricks, J., Lauer, A., Kurcher, B., Slowik, J. G., Rosenlof, K. H., Thompson, T. L., Langford, A. O., Loewenstein, M., and Aikin, K. C.: Single-Particle Measurements of Midlatitude Black Carbon and Light-Scattering Aerosols from the Boundary Layer to the Lower Stratosphere, J. Geophys. Res., 111, D16207, doi:10.1029/2006jd007076, 2006.

Sheridan, P. J., Arnott, W. P., Ogren, J. A., Andrews, E., Atkinson, D. B., Strawa, A. W., Varma, R., and Virkkula, A.: The Reno Aerosol Optics Study: An Evaluation of Aerosol Absorption Measurement Methods, Aerosol Sci. Tech., 39, 1-16, 2005.

Schwarz, J. P., Gao, R. S., Fahey, D. W., Thomson, D. S., Watts, L. A., Wilson, J. C., Reeves, J. M., Darbeheshti, M., Baumgardner, D. G., Kok, G. L., Chung, S. H., Schulz, M., Hendricks, J., Lauer, A., Kurcher, B., Slowik, J. G., Rosenlof, K. H., Thompson, T. L., Langford, A. O., Loewenstein, M., and Aikin, K. C.: Public Health Benefits of Strategies to Reduce Greenhouse-Gas Emissions: Health Implications of Short-Lived Greenhouse Pollutants, The Lancet, 374, 2091-2103, 2009.

Somanathan, S., Flynn, P. C., and Szymanski, J.: The Northwest Passage: A Simulation, Transportation Research Part A, 43, 127135, 2009.

Timco, G. W. and Johnson, D. W.: Arctic Ice Regime Shipping System, edited by: Center, C. H., Canadian Hydraulics Center, National Research Council of Canada, Ottawa, Canada, 2003.

Timco, G. W., Kubat, I., and Johnston, M.: Scientific Basis for the Canadian Ice Regime System, 18th International Conference on Port and Ocean Engineering under Arctic Conditions, Potsdam, NY, USA, 2005.

US-EPA: Analysis of Commercial Marine Vessels Emissions and Fuel Consumption Data, United States Environmental Protection Agency, 2000.

Wettstein, R. and Brown, D.: Derating: A Solution for High Fuel Savings and Lower Emissions, Wartsila Corporation, 2008.

Williams, E., Lerner, B., Murphy, P., Herndon, S. C., and Zahniser, M. S.: Emissions of $\mathrm{NO}_{\mathrm{x}}, \mathrm{SO}_{2}, \mathrm{CO}$, and $\mathrm{C}_{2} \mathrm{H}_{4}$ from Commercial Marine Shipping During Texas Air Quality Study (TexAQS) 2006, J. Geophys. Res., 114, D21306, doi:10.1029/2009JD012094, 2009.

Winebrake, J. J., Corbett, J. J., Green, E. H., Lauer, A., and Eyring, V.: Mitigating the Health Impacts of Pollution from Oceangoing Shipping: An Assessment of Low-Sulfur Fuel Mandates, Environ. Sci. Technol., 43, 4776-4782, doi:10.1021/es803224q, 2009. 